\title{
Hydrothermal ore mineralization from the Polish part of the Tatra Mts., Central Western Carpathians
}

\author{
Magdalena Sitarz ${ }^{1}$, Bożena Gołębiowska², Krzysztof Nejbert ${ }^{3}$, \\ Dimitrina Dimitrova ${ }^{4}$, Rastislav Milovský ${ }^{5}$
}

${ }^{1}$ Tatra National Park, Zakopane, Poland; AGH University of Science and Technology, Department of Mineralogy, Petrography and Geochemistry, Krakow, Poland; e-mail: sitarz@agh.edu.pl (corresponding author)

${ }^{2}$ AGH University of Science and Technology, Department of Mineralogy, Petrography and Geochemistry; Krakow, Poland; e-mail: goleb@agh.edu.pl; ORCID ID:0000-0002-4103-1124

${ }^{3}$ University of Warsaw, Institute of Geochemistry, Mineralogy and Petrology; Warsaw, Poland;

e-mail: knejbert@uw.edu.pl; ORCID ID: 0000-0002-0021-2172

${ }^{4}$ Geological Institute, Bulgarian Academy of Sciences; 1113 Sofia, Bulgaria;

e-mail:didi@geology.bas.bg; ORCID ID: 0000-0001-8008-394X

${ }^{5}$ Slovak Academy of Sciences, Earth Science Institute; Banská Bystrica, Slovakia;

e-mail:milovsky@savbb.sk; ORCID ID: 0000-0003-1880-865X

(c) 2021 Authors. This is an open access publication, which can be used, distributed and reproduced in any medium according to the Creative Commons CC-BY 4.0 License requiring that the original work has been properly cited.

Received: 11 August 2021; accepted: 23 October 2021; first published online: 1 December 2021

\begin{abstract}
Several areas with hydrothermal ore mineralization are present in the Polish part of the Western Tatra Mts. Massive and disseminated sulfides, mainly minerals from the tetrahedrite group and chalcopyrite, fill quartz veins accompanied by siderite, dolomite and baryte - many of these were mined between the $16^{\text {th }}$ and $18^{\text {th }}$ century. This paper presents information on the mineralogy of the common sulfides and the preliminary studies of both the isotopic composition of sulfur in tetrahedrite as well as the origin of hydrothermal fluids. The most common primary sulfide minerals in the ores are tetrahedrite- $(\mathrm{Zn})$ and tetrahedrite-(Fe) corresponding to $\mathrm{Zn}$ ranges from 1.83 to 5.87 wt.\% (0.47-1.44 apfu), and Fe from 1.63 to 5.05 wt.\% (0.48-1.52 apfu). The substitution of As for Sb shows maximum As content of $7.25 \mathrm{wt} . \%$ (1.588 apfu) which corresponds to the $\mathrm{Sb} /(\mathrm{Sb}+\mathrm{As})=0.60$. Both varieties show substitutions of $\mathrm{Bi}$ and $\mathrm{Hg}$, up $0.6 \mathrm{wt} . \%$ (0.049 apfu) and $0.96 \mathrm{wt} . \%$ (0.081 apfu), respectively, and content of trace elements: Co (max. 976 ppm), Cd (max. 735 ppm), In (max. 14 ppm). Chalcopyrite, pyrite, and galena show compositions close to the ideal formula. Differences in the content of trace elements in the studied tetrahedrite and chalcopyrite were explained by element partitioning between these minerals. The distributions of In, Ga and Sn in the studied minerals indicate that the mineralization was formed at low temperature and pressure. The homogenization temperature of the primary inclusions in quartz in the range of $120-174^{\circ} \mathrm{C}$ indicate the origin of mineralization in low temperature stage from low salinity fluids (up to $17.92 \mathrm{wt} . \% \mathrm{NaCl}$ eq.). Stable $\delta^{34} \mathrm{~S}$ isotopes in minerals of the tetrahedrite group suggest that the igneous fluids might be one of the sources from which ores were crystallized.
\end{abstract}

Keywords: tetrahedrite, hydrothermal ore mineralization, fluid inclusions, LA-ICP-MS study, Tatric Superunit, Polish part of the Western Tatra Mts., Poland

\section{INTRODUCTION}

The Western Carpathians, representing the northernmost part of the Alpine-Carpathian orogenic belt, are traditionally divided into the Outer, Central and Inner Western Carpathians (Hók et al. 2019). The Central Western Carpathians comprise (from the north to the south) three crustal superunits: Tatric, Veporic and Gemeric. The present structural pattern of the Western Carpathians resulted 
from a Cretaceous-Tertiary subduction-collision (Plašienka et al. 1997, Bezák et al. 2011). Hydrothermal ore mineralization in the crystalline basement of the Central Western Carpathians is common and its origin is similar in all tectono-structural superunits (Majzlan et al. 2001, 2020, Mikuš \& Chovan 2003). It usually occurs in the form of veins, nests and stockworks (Majzlan 2001, Radvanec et al. 2004, Gawęda et al. 2007, Hurai et al. 2008) and their ore mineralization consists of various minerals (Bakos 2003, Gawęda et al. 2007, Majzlan et al. 2016, Majzlan et al. 2020). It is generally accepted that the mineralization took place during hydrothermal activity connected with either the Variscan or Cretaceous granitoid magmatism (Bakos 2003, Makovicky et al. 2007), or is related to the Alpine magmatic-metamorphic processes (Hurai et al. 2002, Števko et al. 2009).

This work is focused on the mineralogical research of hydrothermal ore mineralization occurring in the western part of the Polish Tatra Mts. in the Tatric Superunit (Fig. 1). It is a $10 \mathrm{~km}$ thick extensive crustal sheet, consisting of the pre-Alpine (generally Variscan) crystalline basement (granitoid plutons emplaced into the medium to high-grade metamorphic rocks) and its sedimentary cover (Mikuš \& Chovan 2003, Andráš \& Chovan 2005, Bezák et al. 2011).

Hydrothermal ore mineralization is present in both magmatic and metamorphic rocks in the Polish part of the Western Tatra Mts. It formed at the last stage of granitic magma crystallization from hydrothermal solutions circulating in the zones of tectonic deformation (Wątocki 1951, Gaweł 1966, Paulo 1970, 1979, Gawęda et al. 2007). The mineralization represents the siderite-quartz-sulfidic type and occurs in form of veins 3 to $10 \mathrm{~cm}$ thick (locally up to $30 \mathrm{~cm}$ ), hosted by cataclased biotite gneisses, amphibolites, quartz diorites, granodiorites and leucocratic granites (Fig. 2) (Pawlica 1916, Paulo 1970, 1979). Some faults in these rocks, originally related principally to late Variscan episodes of igneous activity, were reactivated during the Alpine orogeny. They dip towards WNW-ESE as well as NE-SW and could serve as migration paths for juvenile hydrothermal solutions genetically related with ore mineralization (Paulo 1979, Gawęda \& Paulo 1998, Gawęda et al. 2001, 2007).

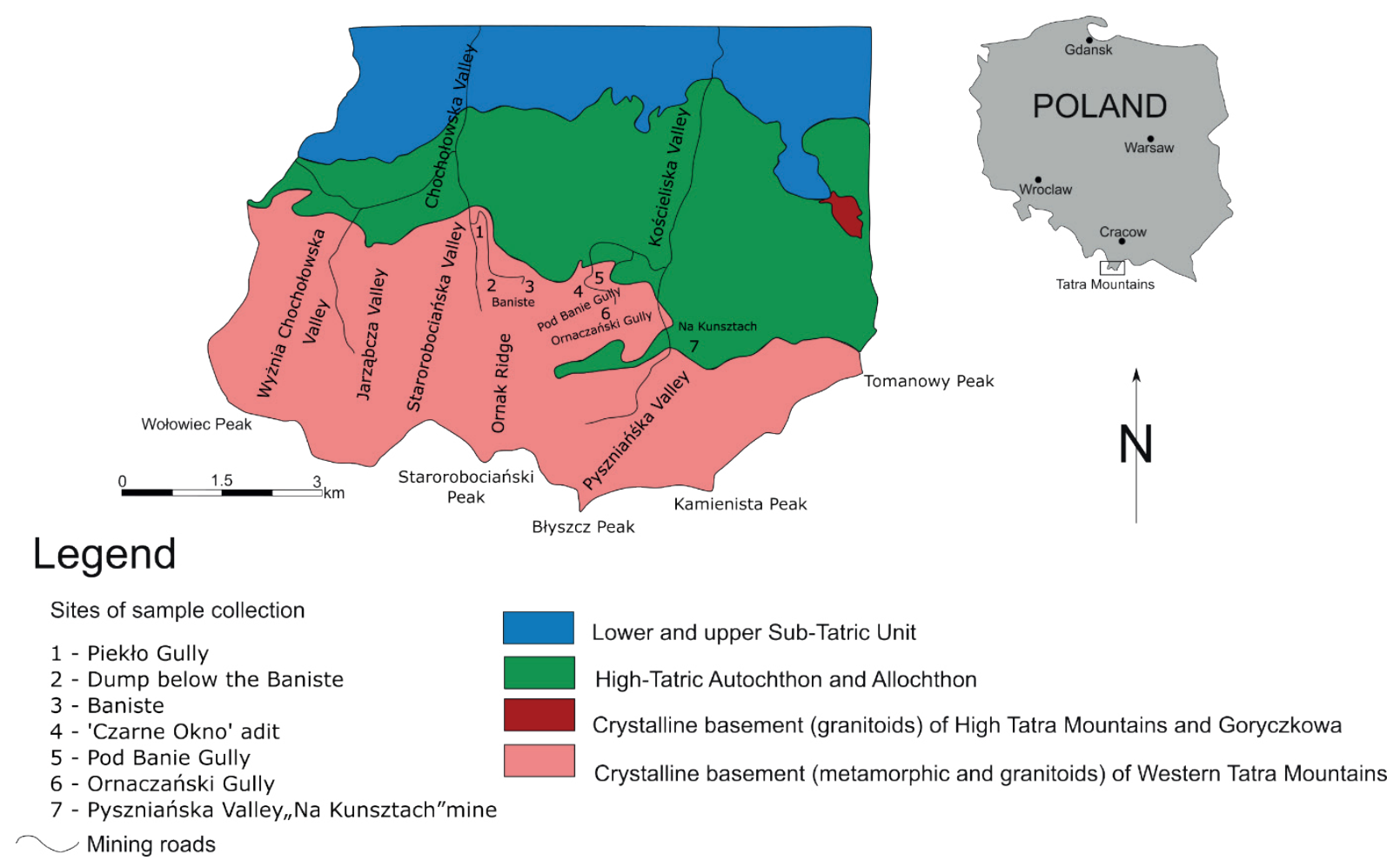

Fig. 1. Simplified geological scheme of the Polish Western Tatra Mts. based on a historical mining map (acc. Jost \& Paulo 1985, modified) 


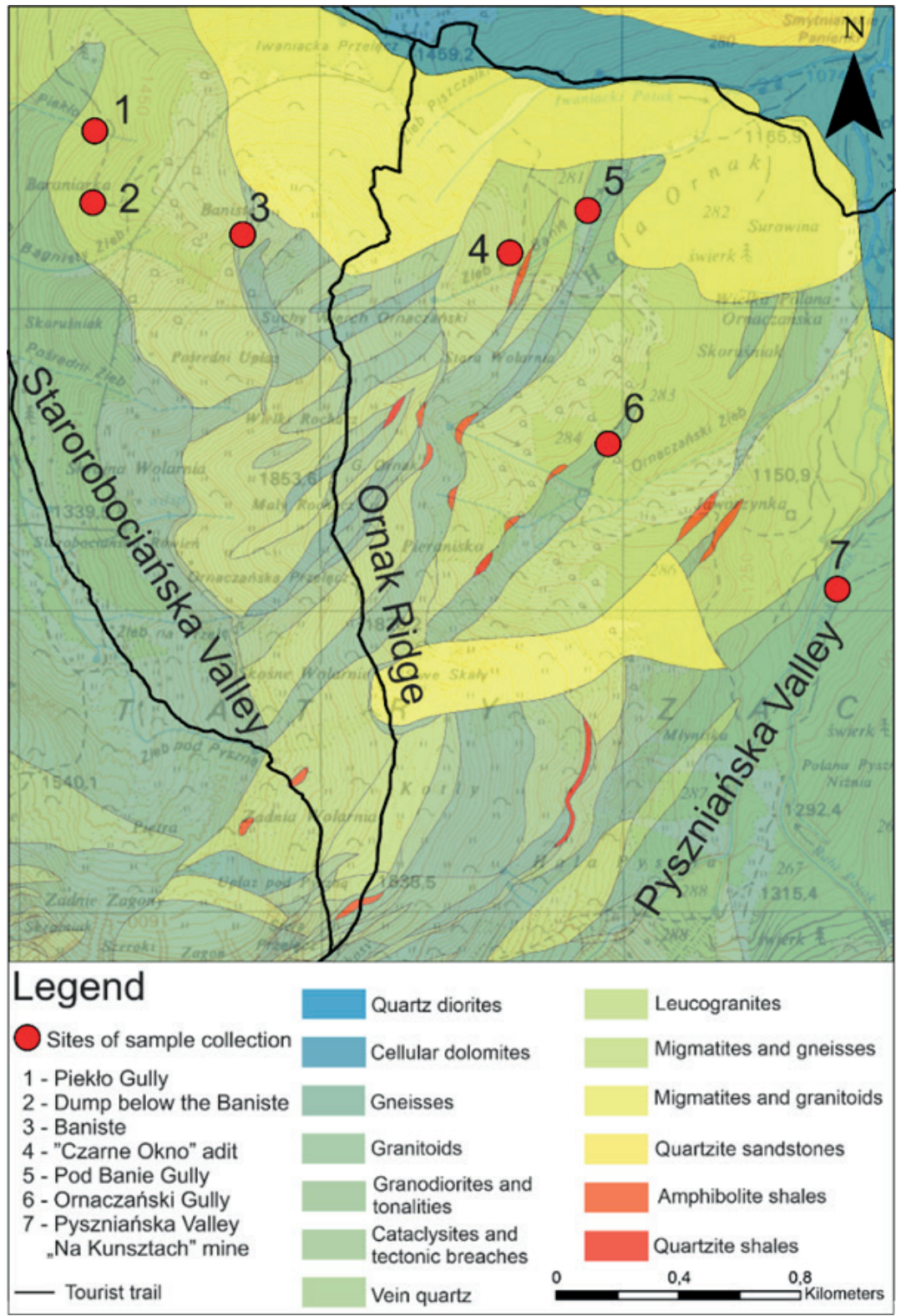

Fig. 2. Detailed geological map of the studied area in the western part of the Tatra Mts. (after Piotrowska 2016, modified)

Three main stages with different types of veins are distinguished in the mineralization; all with quartz as the gangue mineral (Pawlica 1916, Kreutz 1918, Wątocki 1951, Paulo 1970, 1979, Gawęda et al. 2007). The external parts of the veins consist of syntectonic carbonates. Ore minerals such as tetrahedrite, chalcopyrite, pyrite and sphalerite build the second, internal syn- or post-tectonic zone. The last stage of the mineralization is represented by baryte and quartz (Paulo 1970, 1979, Gawęda \& Paulo 1998, Gawęda et al. 2007). Goethite, covellite, cuprite, silver phases, azurite, malachite and
Mn-oxide dendrites represent the supergene zone occurring on the surface of the veins (Paulo 1970, Gawęda et al. 2007).

The hydrothermal ore mineralization in the Polish part of the Western Tatra Mts. was exploited between the $16^{\text {th }}$ and $18^{\text {th }}$ century. The Pyszniańska Valley and the eastern and western parts of the Ornak Ridge were the three main areas of mining activity (Wątocki 1951, Gaweł 1966, Kutaś 2005). Seven adits situated one above the other in the eastern part of the Ornak Ridge at about $1400 \mathrm{~m}$ a.s.l. were excavated first (Liberak 1927, 
Gaweł 1966, Jost 2004). The first one, called 'Czarne Okno' was $60 \mathrm{~m}$ long. On the western part of the Ornak Ridge, mining exploitation was conducted at $1600 \mathrm{~m}$ a.s.l. Twelve adits were excavated there along the horizontal path (Gaweł 1966). Mining works in the Pyszniańska Valley were different than in the previously described areas. Due to the location of the ore veins at the valley bottom, exploitation was conducted by means of two shafts, for the first time in the Polish part of the Tatra Mts. (Zwoliński 1961, 1962, Gaweł 1966). However, only one of them, $40 \mathrm{~m}$ deep, proved profitable and its exploitation was continued. Finally, at the end of the $18^{\text {th }}$ century, ore mining in the Polish Tatras came to an end due to the insufficient metal ore resources for profitable mining.

The main goal of this paper is to present the results of mineralogical studies on remnants of the hydrothermal ore mineralization still present in the Polish part of the Western Tatra Mts., focusing on the chemical characterization and primary studies of the origin of hydrothermal fluids. For this purpose, samples of ores with varying types of mineralization were also collected from localities not mentioned before in the literature. The chemical compositions of the ores, combined with studies of trace elements, fluid inclusions and isotopic analysis $\delta^{34} \mathrm{~S}$, should enable preliminary discussion on the origin of the studied mineralization and on its comparison with the results of ore studies from the Slovakian part of the Tatra Mts., and other parts of the Tatric Superunit.

\section{MATERIALS AND METHODS}

\section{Sample collection}

Field work, including the collection of ore samples, was carried out in three main locations of ore mineralization in the Polish part of the Western Tatra Mts.:

1) in three places in the western part of the Ornak Ridge (Piekło Gully, dump below the Baniste and Baniste);

2) in three places in the eastern part of the Ornak Ridge (Pod Banie Gully, 'Czarne Okno' adit, and Ornaczański Gully);

3) in the Pyszniańska Valley ('Na Kunsztach' mine).
The collection of ore samples was strictly limited as the field studies were conducted in the Tatra National Park. The amount and size of collected samples was specified according to the permission granted by the Polish Ministry of Climate and Environment as well as the Tatra National Park. Additionally, they could only be carried out by means of non-invasive methods. Generally, the ore samples were collected from old mine dumps. In preserved adits, only gangue minerals were found. The mine works were located using geological maps, historical data, and an old mining map (Jost \& Paulo 1985). In addition, difficulties in the sample collection were caused by the demanding mountainous terrain.

In the western part of the Ornak Ridge, the first adit was discovered in the Piekło Gully, at $1400 \mathrm{~m}$ a.s.l. The entrance to this adit is ca. $1 \mathrm{~m}$ in diameter. It consists of two corridors, which are periodically flooded. Below the Baniste Gully, a rather small dump was discovered, while two large dumps were found in the gully itself, in dense growths of mountain pine (Fig. 3A). The entrance to one of the mines in this area is still preserved with a corridor ca. $5 \mathrm{~m}$ long. The samples in the eastern part of the Ornak Ridge were collected from an adit in the Ornaczański Gully (Fig. 3B). The largest of them consists of three corridors with about $35 \mathrm{~m}$ of total length. Ore deposits located in the Pod Banie Gully are situated at $1400 \mathrm{~m}$ a.s.l. Samples were found at the mouth of the gully and in its upper parts. A group of at least five places which might be remnants after ore mining was discovered. One of the places, the one known as 'Czarne Okno', is still well preserved (Fig. 3C). The entrance to the adit is tight but its interior is about $2 \mathrm{~m}$ high. The total length of the adit is about $70 \mathrm{~m}$ and consists of the lower and upper horizons. Mines in the Pyszniańska Valley took the form of shafts. A huge dump $30 \mathrm{~m}$ long, $10 \mathrm{~m}$ wide and 3-5 m high and a crater after a mine shaft, $8 \mathrm{~m}$ deep and $10 \mathrm{~m}$ wide, are the remnants of mining in this area (Fig. 3D). In all locations, the residues on the dumps are very poor in terms of ore mineralization. Most likely, the ore veins were almost completely exploited during the historical mining work. 

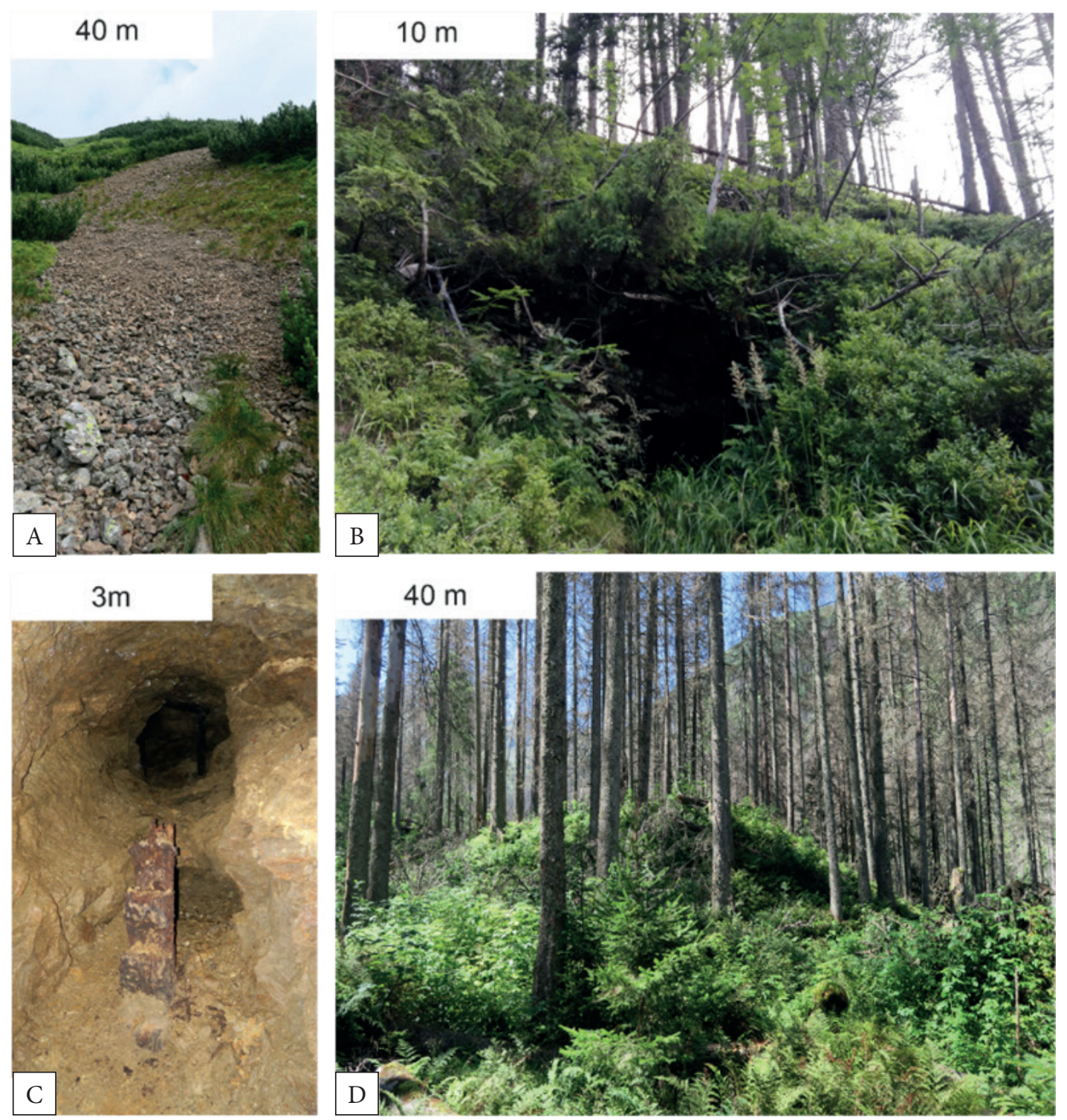

Fig. 3. The current condition of abandoned adits and mining galleries in the Tatra Mts. Relics of historical mining: A) old mine dump in the western part of the Ornak Ridge; B) entrance to an old mine in the eastern part of the Ornak Ridge; C) gallery in mine in the eastern part of the Ornak Ridge; D) old mine dump at Pysznianska Valley

\section{Methods}

Detailed microscopic studies of ores were conducted in both polarized and reflected light using a Zeiss Primotech microscope with Labscope software. The microphotography was taken in reflected light. Microphotography of fluid inclusions was taken in polarized light using a Nikon Optiphot-2 microscope with DeltaPix Insight software and an Invenio $5 \mathrm{~S}$ camera.

Qualitative and initial semi-quantitative analyses of chemical compositions of the ores (SEM-EDS) were performed using a FEI Quanta 200 FEG scanning electron microscope at the AGH UST Krakow, Poland, equipped with energy-dispersive X-ray spectroscopy (EDS) detector. The system operated at $25 \mathrm{kV}$ accelerating voltage in high- and lowvacuum modes.

The quantitative chemical analyzes were performed at the Critical Elements Laboratory AGHKGHM in Krakow using a JEOL JXA-8230 Super Probe electron-probe microanalyzer (EPMA) with five wavelength X-ray dispersive spectrometry (WDS) detectors and an energy-dispersive 
spectrometry (EDS) system. The microprobe operated under the following conditions: accelerating voltage of $20 \mathrm{kV}$, beam current of $20 \mathrm{nA}$, peak time of $20 \mathrm{~s}$, and background time of $10 \mathrm{~s}$. Standards (analytical lines, diffracting crystals and mean detection limits in weight percent (wt.\%) element) were as follows: a. arsenopyrite (As $L \alpha$, TAP, 0.07), bismuthinite (Bi Ma, PET, 0.13), antimony telluride (Te La, PET, 0.08), cadmium (Cd La, PET, 0.19), indium arsenide (In La, PET, 0.07), chalcopyrite (Cu Ka, LIF, 0.03), SnS (Sn La, PET, 0.02), $\mathrm{FeS}_{2}$ (Fe Ka, LIF, 0.02), sphalerite ( $\mathrm{Zn} \mathrm{Ka}$, LIF, 0.04), alabandite (Mn Ka, LIF, 0.02), galena ( $\mathrm{Pb} \mathrm{Ma}, \mathrm{PET}, 0.05$ ), stibnite (Sb La, PET, 0.02), $\mathrm{FeS}_{2}$ (S Ka, PET, 0.02), $\mathrm{Ag}_{2} \mathrm{~S}$ (Ag La, PET, 0.02), cinnabar (Hg Ma, PET, 0.05) and antimony selenide (Se La, TAP, 0.12) - analysis for sulfides; b. diopside (Ca Ka, PET, 0.07), rhodonite (Mn Ka, LIF, 0.07), $\mathrm{NiO}$ (Ni Ka, LIF, 0.09), cobalt (Co Ka, LIF, 0.07), hematite (Fe Ka, LIF, 0.06), anhydrite (S Ka, PET, 0.04 ), celestine (Sr La, PET, 0.06), willemite ( $\mathrm{Zn}$ $\mathrm{Ka}$, LIF, 0.12), baryte (Ba La, PET, 0.06), albite (Na $\mathrm{Ka}$, TAP, 0.09), diopside (Mg Ka, TAP, 0.09), albite (Al Ka, TAP, 0.09) - analysis for sulfates. The raw data were reduced with the ZAF routine using a JEOL software for the electron microprobe.

In situ analysis of trace elements in tetrahedrite and chalcopyrite was conducted by laser ablation inductively coupled plasma mass spectrometry (LA-ICP-MS) using a NWR UP193FX excimer laser ablation system combined with PerkinElmer ELAN DRC-e ICP-MS instrument at the laboratory in the Geological Institute, Bulgarian Academy of Sciences (Sofia, Bulgaria). The operating conditions of the laser system are as follows: homogeneous energy density on the sample $5.5-5.6 \mathrm{~J} / \mathrm{cm}^{2}$ (at $35 \mu \mathrm{m}$ pit); $4.9-5.0 \mathrm{~J} / \mathrm{cm}^{2}$ (at $25 \mu \mathrm{m}$ pit); $4.7-4.8 \mathrm{~J} / \mathrm{cm}^{2}$ (at $20 \mu \mathrm{m}$ pit), repetition rate $5-6 \mathrm{~Hz}$, pit sizes 20 $35 \mu \mathrm{m}$. The following isotope masses were monitored throughout the experiment with dwell time per isotope: $40 \mathrm{~ms}-{ }^{197} \mathrm{Au} ; 30 \mathrm{~ms}-{ }^{107} \mathrm{Ag} ; 20 \mathrm{~ms}-$ ${ }^{74} \mathrm{Ge},{ }^{82} \mathrm{Se},{ }^{115} \mathrm{In},{ }^{125} \mathrm{Te},{ }^{202} \mathrm{Hg} ; 10 \mathrm{~ms}-{ }^{34} \mathrm{~S},{ }^{49} \mathrm{Ti},{ }^{51} \mathrm{~V}$, ${ }^{53} \mathrm{Cr},{ }^{55} \mathrm{Mn},{ }^{57} \mathrm{Fe},{ }^{59} \mathrm{Co},{ }^{60} \mathrm{Ni},{ }^{65} \mathrm{Cu},{ }^{66} \mathrm{Zn},{ }^{71} \mathrm{Ga},{ }^{75} \mathrm{As}$, ${ }^{95} \mathrm{Mo},{ }^{111} \mathrm{Cd},{ }^{118} \mathrm{Sn},{ }^{121} \mathrm{Sb},{ }^{181} \mathrm{Ta},{ }^{182} \mathrm{~W},{ }^{203} \mathrm{Tl},{ }^{208} \mathrm{~Pb},{ }^{209} \mathrm{Bi}$. External standardization was done against NIST SRM 610 (glass) and USGS Mass 1 (sulfide) using $\mathrm{Cu}$ contents measured by EPMA for each spot as internal standard. Data reduction was conducted using Sills software (Guillong et al. 2008).
Fluid inclusions studies were performed in about $200 \mu \mathrm{m}$ thick double polished sections. To determine the shape and classify the timing of formation of the inclusion relative to the host, mineral petrographic documentation at room temperature was conducted. Phase transitions have been measured using Linkam HFS 91 freezing-heating stage mounted on Nikon Optiphot-2 microscope with the lenses: Nikon M Plan 40/055 ELWD and Nikon M Plan 100/0.75 SLWD. The samples were initially heated with the speed of $40^{\circ} \mathrm{C} / \mathrm{min}$, then the speed was gradually reduced from 10 to $1^{\circ} \mathrm{C} / \mathrm{min}$, c.a. $5^{\circ} \mathrm{C}$ before the final homogenization temperature was attained. Eutectic $\left(T_{\mathrm{e}}\right)$ and final ice melting $\left(T_{\mathrm{m}}\right)$ temperatures were only measured for larger-sized fluid inclusions. Observations of changes in inclusions occurring near the expected phase transitions were carried out at a rate of $0.1^{\circ} \mathrm{C} / \mathrm{min}$. The salinity of the fluids was estimated by recording the final ice melting temperature. During the experiment the examined samples were initially rapid frozen to a temperature of c.a. $-120^{\circ} \mathrm{C}$ and then gradually heated. The heating rate was reduced from 10 to $0.1^{\circ} \mathrm{C} / \mathrm{min}$ close to the expected phase transitions. Each measurement was repeated three times. Salinity was calculated from the melting temperatures using AqSo5e software (Bakker 2019).

Stable sulfur isotopes were measured on isotope ratio mass spectrometer MAT 253 (Thermo Scientific) coupled with elemental analyzer Flash2000 HT (Earth Science Institute, Slovak Academy of Sciences, Banská Bystrica). Sulfide powders of 70-360 $\mu \mathrm{g}$ were drilled by Micromill (New Wave Research) from polished sections and wrapped into tin capsules with same amount of $\mathrm{V}_{2} \mathrm{O}_{5}$. They were combusted in quartz glass reactor at $1000^{\circ} \mathrm{C}$ in stream of oxygen, and further reacted on chromium oxide, electrolytic copper and silvered cobaltous/cobaltic oxide. The evolved $\mathrm{SO}_{2}$ gas was purified in gas chromatograph, lead into mass spectrometer via a Conflo IV continuous-flow interface and measured against two reference $\mathrm{SO}_{2}$ gas peaks. Raw isotope ratios were calibrated using international reference materials IAEA-S2 and IAEA-S3 (both $\mathrm{Ag}_{2} \mathrm{~S}$ ) with +22.70 and $-32.30 \%$ CDT, all measurements are reported as permil vs. CDT, typical precision of measurement is $0.21 \%$. 


\section{RESULTS}

\section{Mineralogy}

Ore mineralization of the Polish part of the Western Tatra Mts. occurs in quartz with siderite \pm baryte veins of varying thickness (Fig. 4A-C). The most abundant mineral phases are tetrahedrite group minerals, chalcopyrite and pyrite, while galena occurs only occasionally.

Minerals of the tetrahedrite group usually form small impregnations up to $0.5 \mathrm{~cm}$ in size and intergrowths with the subordinate $\mathrm{Cu}-, \mathrm{Fe}-$ base-metal sulfides (Figs. 4C, 5A-F). Larger aggregates of the tetrahedrite as well as $2-5 \mathrm{~mm}$ are sometimes visible in the quartz. Chalcopyrite occurs both in form of inclusions in tetrahedrite and sometimes as larger isolated aggregates (Fig. 5AC, E). Pyrite occurs as small, mostly cubic crystals of up to $50 \mu \mathrm{m}$ (Fig. 5E). Minute grains of galena (up to a few micrometers) are usually disseminated in the vein quartz (Fig. 6E). Nevertheless, single larger aggregates, up to $0.5 \mathrm{~mm}$, were also observed, e.g., in ores from the eastern part of the Ornak Ridge (Fig. 5F). Secondary minerals, e.g., $\mathrm{Cu}$ carbonates (malachite, azurite), $\mathrm{Sb}-, \mathrm{Fe}-$ and
Mn-oxides or pseudomorphs of goethite after pyrite cubes were recognized as weathering products of the primary ores (Fig. 4B). As a result, the tetrahedrite aggregates are overgrown by the secondary minerals which develop toward the grain interiors (Fig. 6A-B, E). Chalcopyrite undergoes similar alteration. It is replaced in the outermost portions by secondary $\mathrm{Cu}$-sulfides, mainly covellite and iron oxides (Fig. 6A). Unrecognized secondary Ag minerals forming fine single grains were identified on tetrahedrite from the Pyszniańska Valley and the Piekło Gully (Fig. 6C, D). They also form fillings in cracks, only $1-2 \mu \mathrm{m}$ in thickness. Moreover, intergrowths of secondary $\mathrm{Cu}$ and $\mathrm{Fe}$ compounds enriched in Ag were detected. Siderite veins associated with the mentioned $\mathrm{Cu}$ sulfidic mineralization are small, up to a few $\mathrm{cm}$ in thickness. Larger siderite veins, up to $20-30 \mathrm{~cm}$ thick, were also noticed. The same observation was made for baryte (e.g. Piekło Gully, Fig. 4A); however siderite is sometimes altered by the oxidation and hydration processes to iron hydroxides. Platy baryte crystals shows compositional zoning in back-scattered-electron (BSE) images due to varying Sr content (Fig. 6F).
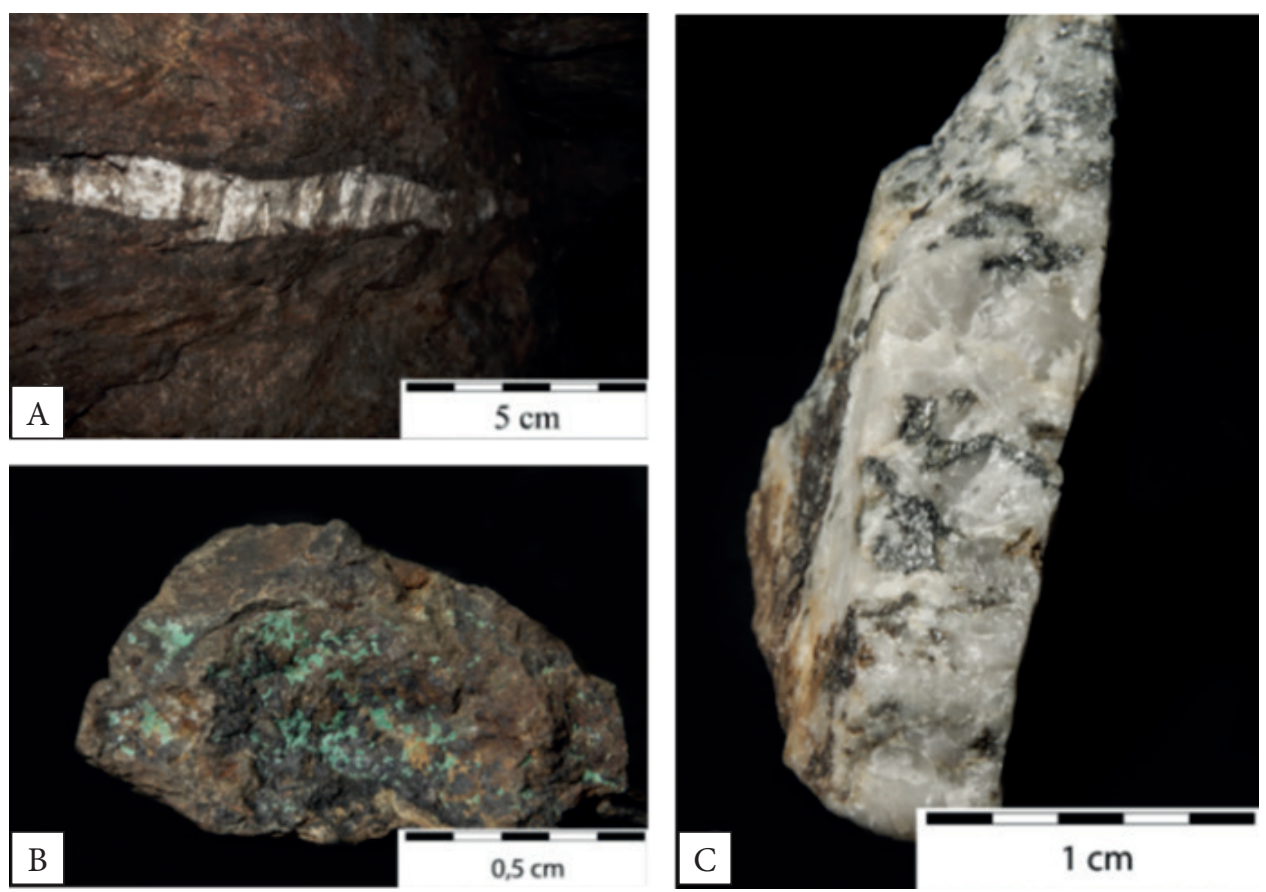

Fig. 4. Examples of hydrothermal ore mineralization from the vicinity of the Ornak Ridge: A) baryte vein in small adit in the western part of the Ornak Ridge; B) secondary Cu-minerals coating a fragment of rich tetrahedrite group minerals from the western part of the Ornak Ridge; C) quartz vein with visible tetrahedrite group minerals from eastern part of the Ornak Ridge 

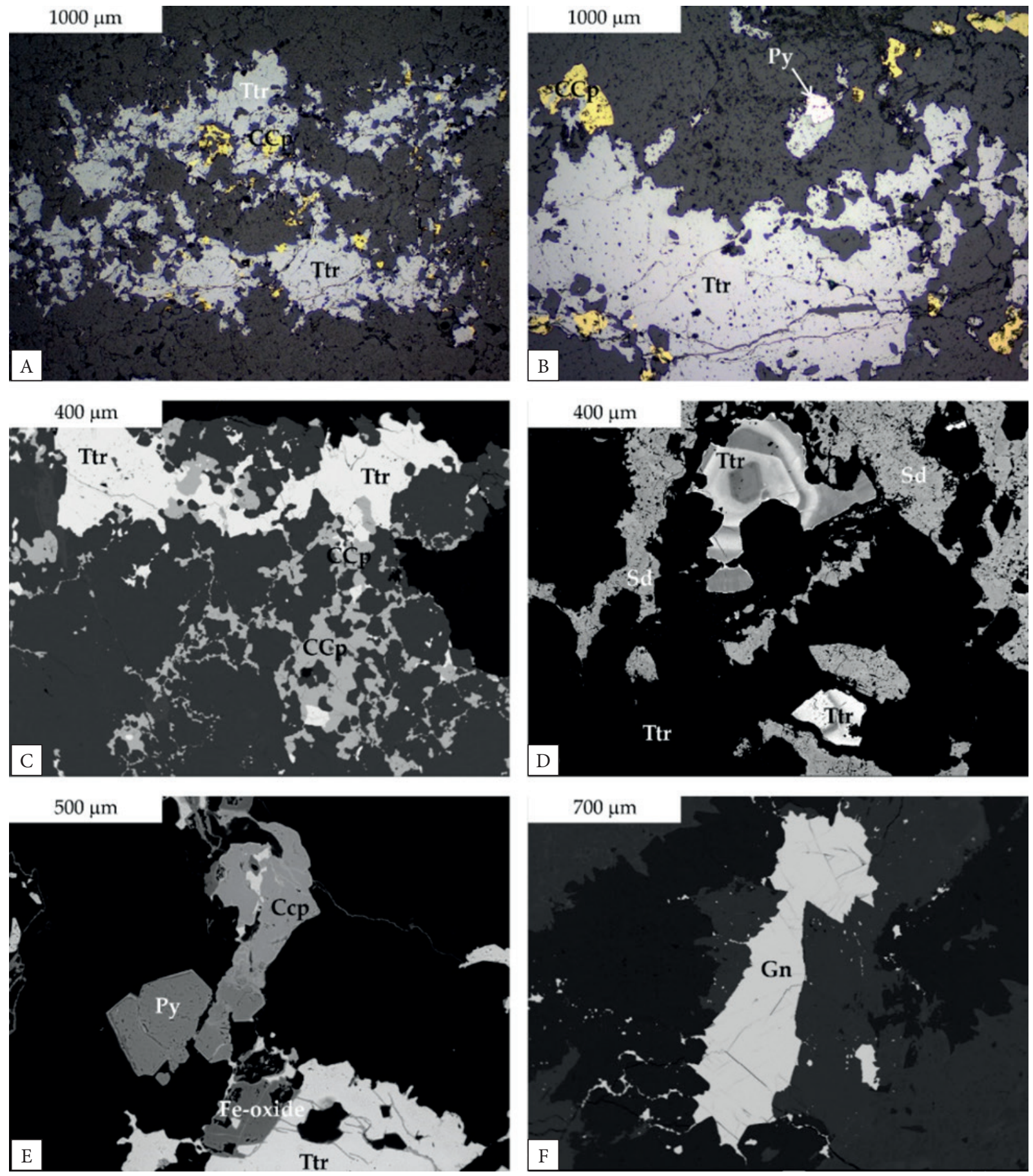

Fig. 5. Reflected-light microscopy $(A-B)$ and SEM-BSE (C-F) images of Cu-sulfidic mineralization from the western part of the Tatra Mts.: A), B) massive tetrahedrite aggregates with intergrowths of chalcopyrite, and pyrite in quartz vein; C) typical association of tetrahedrite and chalcopyrite; D) zoned crystal of tetrahedrite co-occurred with siderite; E) idiomorphic crystals of pyrite and aggregates of chalcopyrite; iron oxides occur as small light grains within tetrahedrite; F) crystals of galena in a quartz vein. Abbreviations: Ttr-tetrahedrite, Ccp-chalcopyrite, Py-pyrite, Gn-galena, Fe-oxide-iron oxides, Sd-siderite, Qz-quartz 

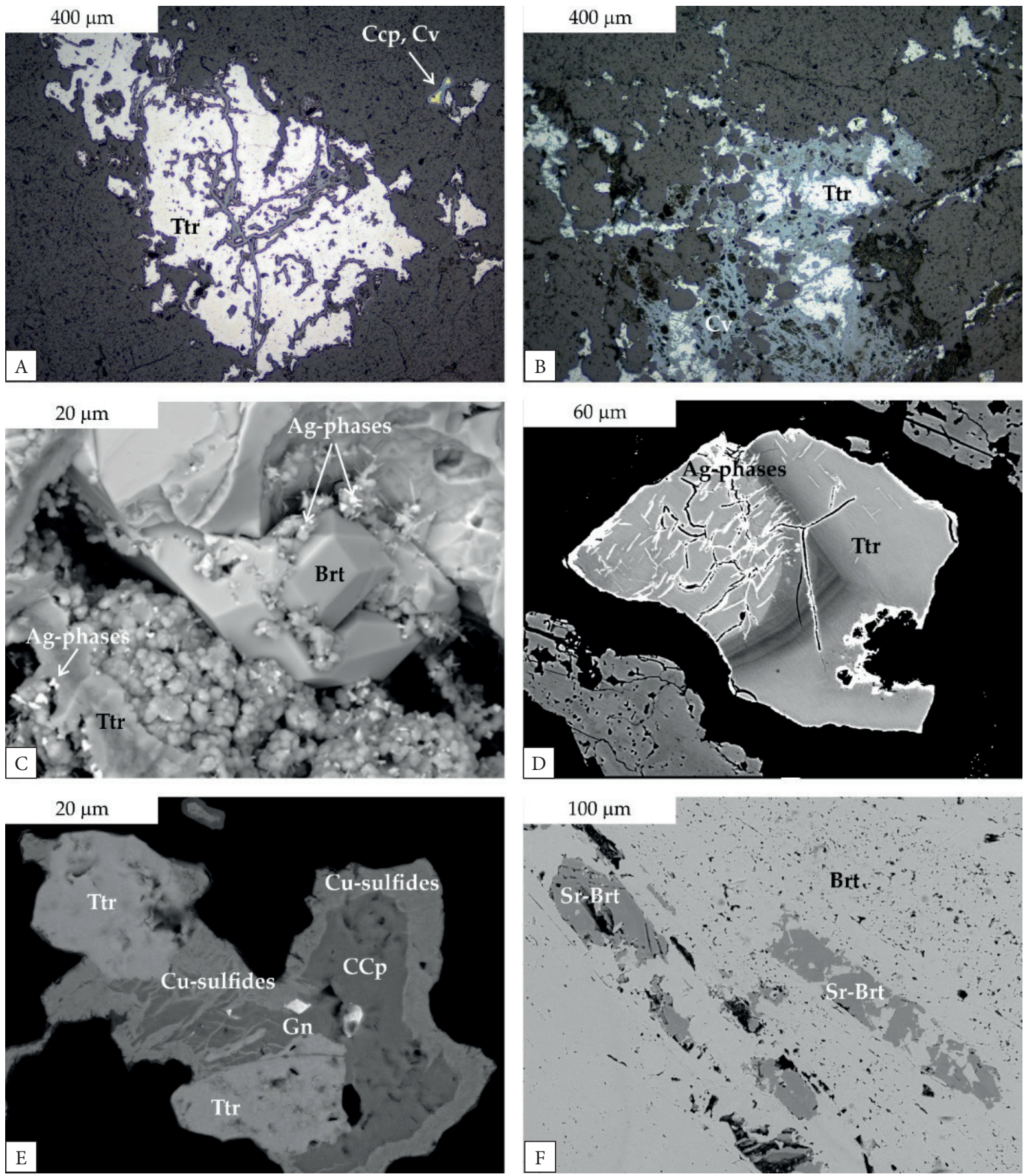

Fig. 6. Reflected-light microscopy (A, B) and SEM-BSE (C-F) images: A), B) secondary alterations of tetrahedrite grains; small veins and cracks filled with secondary minerals. Altered chalcopyrite overgrown by secondary covellite; $C), D$ ) secondary silver minerals formed on tetrahedrite surface or filling small cracks within it; E) tetrahedrite and chalcopyrite with visible secondary alteration and inclusion of galena; gray minerals correspond to secondary silver-enriched copper sulphides; F) intergrowths of Sr-rich (grey) andSr-freebaryte (light). Abbreviations: Ttr-tetrahedrite, Ccp-chalcopyrite, Cv-covellite, Gn-galena, Brt-baryte 


\section{Chemical composition}

The chemical composition of tetrahedrite group minerals from the Polish part of the Western Tatra Mts. is presented in Table 1. According to the current International Mineralogical Association nomenclature (Biagoni et al. 2020) based on occupancies of the $\mathrm{B}$ and $\mathrm{C}$ sites in the tetrahedrite structure ascribed by the generalized formula $\mathrm{A}_{6}\left(\mathrm{~B}_{4} \mathrm{C}_{2}\right) \mathrm{D}_{4} \mathrm{Y}_{12} \mathrm{Z}$, where $\mathrm{A}=\mathrm{Cu}^{+}, \mathrm{Ag}^{+}, \square$ (vacancy), and $\left(\mathrm{Ag}_{6}\right)^{4+}$ clusters; $\mathrm{B}=\mathrm{Cu}^{+}$and $\mathrm{Ag}^{+}$; $\mathrm{C}=\mathrm{Zn}^{2+}, \mathrm{Fe}^{2+}, \mathrm{Hg}^{2+}, \mathrm{Cd}^{2+}, \mathrm{Mn}^{2+}, \mathrm{Cu}^{2+}, \mathrm{Cu}^{+}$, and $\mathrm{Fe}^{3+} ; \mathrm{D}=\mathrm{Sb}^{3+}, \mathrm{As}^{3+}, \mathrm{Bi}^{3+}$, and $\mathrm{Te}^{4+} ; \mathrm{Y}=\mathrm{S}^{2-}$, and $\mathrm{Se}^{2-}$; and $\mathrm{Z}=\mathrm{S}^{2-}, \mathrm{Se}^{2-}$, and $\square$ (Biagioni et al. 2020), the studied phases represent tetrahedrite-(Fe) $\left(\mathrm{Ag}_{0.175} \mathrm{Cu}_{5.825}\right)_{6}\left(\mathrm{Cu}_{4.199} \mathrm{Zn}_{0.879} \mathrm{Fe}_{1.036} \mathrm{Hg}_{0.028} \mathrm{~Pb}_{0.01}\right)_{6.143}$ $\left(\mathrm{As}_{0.761} \mathrm{Sb}_{3.223} \mathrm{Bi}_{0.016}\right)_{4}\left(\mathrm{~S}_{12.944} \mathrm{Se}_{0.002}\right)_{12.946}$, and tetrahedrite-(Zn) $\left(\mathrm{Ag}_{0.277} \mathrm{Cu}_{5.723}\right)_{6}\left(\mathrm{Cu}_{4.162} \mathrm{Zn}_{1.135} \mathrm{Fe}_{0.810} \mathrm{Hg}_{0.034}\right.$ $\left.\mathrm{Pb}_{0.01}\right)_{6.142}\left(\mathrm{As}_{0.639} \mathrm{Sb}_{3.350} \mathrm{Bi}_{0.011}\right)_{4}\left(\mathrm{~S}_{12.889} \mathrm{Se}_{0.005}\right)_{12.894}$ (Fig. 7). In the Pyszniańska Valley, the dominance of $\mathrm{Zn}$-tetrahedrite is observed. In other locations, no clear dominance of chemical varieties of tetrahedrite were noticed. The content of $\mathrm{Zn}$ ranges from 1.83 to 5.79 wt.\% (0.47-1.44 apfu; eastern part of the Ornak Ridge) and Fe from 1.63 to 5.05 wt.\% (0.48-1.52 apfu; eastern part of the Ornak Ridge; Fig. 7). Deficiencies in the $\mathrm{C}$ site are completed by $\mathrm{Hg}$ (up to 0.96 wt.\%; eastern part of the Ornak Ridge), Cd (up to 0.35 wt.\%; western part of the Ornak Ridge) and a trace of $\mathrm{Pb}$ (up to 0.15 wt.\%; eastern part of the Ornak Ridge). Figure 8 shows a correlation between As and $\mathrm{Sb}$. The substitution As for Sb shows the maximum As content of 7.25 wt.\% (western part of the Ornak Ridge) which corresponds to the ratio $\mathrm{Sb} /(\mathrm{Sb}+\mathrm{As})=0.60$ at the Bi absence and the lowest content 0.1 As wt.\% (eastern part of the Ornak Ridge) corresponding to the $\mathrm{Sb} /(\mathrm{Sb}+\mathrm{As})=0.99$ also at the Bi absence. Bismuth is, at most a trace component, reaching the maximum content of 0.60 wt.\% (0.05 apfu Bi; Pyszniańska Valley). The maximum Ag content of 4.06 wt.\% (0.635 apfu) was found in tetrahedrite-(Zn) from the western part of the Ornak Ridge, at average Ag content in the studied tetrahedrites of $1.58 \mathrm{wt} . \%$.

Chalcopyrite shows no significant compositional differences (Tab. 2). EPMA analyses showed Ag admixtures up to a maximum content $0.5 \mathrm{wt} . \%$ (western part of the Ornak Ridge), while $\mathrm{Pb}, \mathrm{Bi}$ and $\mathrm{Hg}$ can be present with maximum contents up to $0.3 \mathrm{wt} . \%$. Pyrite contains trace As (up to $0.45 \mathrm{wt} . \%$; eastern part of the Ornak Ridge) and $\mathrm{Cu}$ (up to max. 1.35 wt.\%; Tab. 3). Galena exhibits no silver or other significant $\mathrm{Pb}$ substituents (Tab. 4).

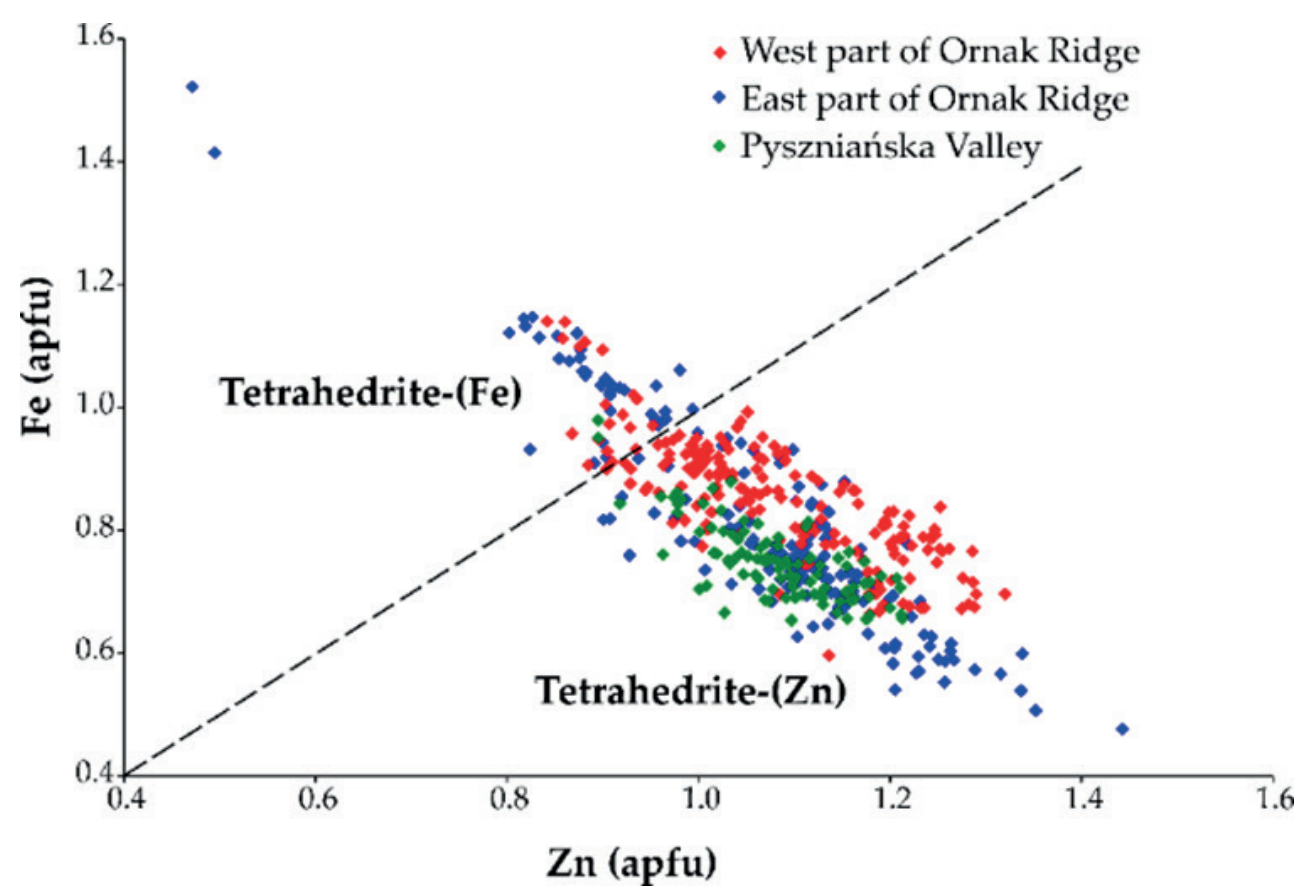

Fig. 7. The Fe-Zn substitution trend in minerals of the tetrahedrite series 
Table 1

Representative WDS analyses of the tetrahedrite group minerals from three areas in the Western Tatra Mts. Samples ZB1, ZB2, TEB1, ZB7 - eastern part of the Ornak Ridge; ZP1, TZ11, BO16 - western part of the Ornak Ridge; DP1, DP14 - Pyszniańska Valley

\begin{tabular}{|c|c|c|c|c|c|c|c|c|c|c|c|c|c|c|c|}
\hline & \multicolumn{5}{|c|}{ Eastern part of the Ornak Ridge } & \multicolumn{5}{|c|}{ Western part of the Ornak Ridge } & \multicolumn{5}{|c|}{ Pyszniańska Valley } \\
\hline & $\begin{array}{c}\text { ZB1- } \\
26\end{array}$ & $\begin{array}{c}\text { ZB2- } \\
13\end{array}$ & $\begin{array}{c}\text { TEB1- } \\
45\end{array}$ & \begin{tabular}{|c} 
TEB1- \\
53
\end{tabular} & B7-9 & $\begin{array}{c}\text { ZP1- } \\
38\end{array}$ & $\begin{array}{c}\text { ZP1- } \\
42\end{array}$ & $\begin{array}{c}\text { ZP1- } \\
47\end{array}$ & $\begin{array}{c}\text { TZ11- } \\
71\end{array}$ & $\begin{array}{c}\text { BO16- } \\
01\end{array}$ & $\begin{array}{c}\text { DP1- } \\
01\end{array}$ & \begin{tabular}{|c} 
DP1- \\
02
\end{tabular} & \begin{tabular}{|c} 
DP1- \\
29
\end{tabular} & $\begin{array}{c}\text { DP1- } \\
10\end{array}$ & $\begin{array}{c}\text { DP14- } \\
10\end{array}$ \\
\hline $\mathrm{Cu}$ & 7.51 & 38.20 & 38.47 & 3.39 & 37.59 & 37.61 & 35.67 & 38.27 & 37.58 & 37.40 & 39.55 & 38.71 & 39.51 & 38.42 & 39.51 \\
\hline $\mathrm{Ag}$ & 1.16 & 1.27 & 0.93 & 1.10 & 1.83 & 2.15 & 4.06 & 2.59 & 1.46 & 1.47 & 1.19 & 1.53 & 1.10 & 1.39 & 0.31 \\
\hline $\mathrm{Zn}$ & 4.47 & 4.11 & 3.20 & 3.38 & 4.91 & 4.24 & 4.99 & 4.37 & 3.41 & 4.54 & 3.59 & 4.35 & 3.57 & 4.70 & 4.18 \\
\hline $\mathrm{Fe}$ & 2.65 & 3.09 & 3.82 & 3.65 & 2.26 & 3.13 & 2.23 & 3.12 & 3.66 & 2.66 & 3.26 & 2.69 & 3.33 & 2.35 & 3.03 \\
\hline $\mathrm{Pb}$ & 0.12 & 0.06 & b.d.l. & b.d.l. & b.d.l. & b.d.l. & b.d.l. & b.d.l. & b.d.l. & b.d.l. & b.d.l. & b.d.l. & b.d.l. & b.d.l. & b.d.l. \\
\hline $\mathrm{Hg}$ & 0.59 & 0.53 & .36 & 0.45 & 0.72 & 0.46 & 0.52 & 0.40 & 0.34 & 0.44 & 0.23 & 0.32 & 0.21 & 0.29 & 0.10 \\
\hline As & 0.54 & 2.54 & 4.32 & 3.44 & 1.16 & 5.95 & 1.22 & 6.22 & 1.34 & 1.01 & 5.38 & 2.92 & 4.95 & 1.85 & 3.25 \\
\hline $\mathrm{Sb}$ & 28.43 & 24.73 & 22.48 & 23.76 & 27.97 & 19.98 & 26.73 & 19.57 & 26.71 & 28.14 & 21.14 & 24.36 & 21.51 & 25.80 & 24.69 \\
\hline $\mathrm{Bi}$ & 11 & 0.21 & 0.30 & 2 & 0.13 & 2 & 0 & 02 & 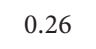 & 16 & 1. & b.d.l. & 02 & 0 & 0.19 \\
\hline Se & b.d.l. & b.d.l. & b.d.l. & 0.06 & b.d.l. & 0.17 & b.d.l. & 0.06 & b.d.l. & b.d.l. & b.d.l. & b.d.l. & b.d.l. & b.d.l. & 0.05 \\
\hline$S$ & 24.88 & 24.97 & 25.52 & 25.24 & 24.17 & 25.43 & 24.52 & 25.69 & 24.87 & 24.44 & 25.10 & 25.03 & 25.36 & 24.84 & 25.44 \\
\hline wt.\% & 0.46 & 99.71 & .38 & 99.68 & 00.74 & 99.23 & 100.17 & 100.48 & 99.61 & 0.26 & 9.44 & 9.91 & 99.79 & 9.85 & 00.74 \\
\hline \multicolumn{16}{|c|}{ Chemical formula based on $\mathrm{Sb}+\mathrm{As}+\mathrm{Bi}=4 \mathrm{apfu}$} \\
\hline $\mathrm{Cu}$ tot & 9.787 & 10.107 & 9.937 & 9.985 & 9.629 & 9.702 & 9.478 & 9.844 & 9.922 & 9.595 & 10.143 & 10.194 & 10.194 & 10.176 & 10.068 \\
\hline $\mathrm{Cu}$ & 822 & 5.802 & 5858 & 823 & 5723 & .674 & 365 & 5.607 & 5.773 & 5.778 & 5.820 & 5.762 & 5.832 & 5.783 & 5.954 \\
\hline $\mathrm{Ag}$ & 0.178 & 0.198 & 0.142 & 0.169 & 0.277 & 0.326 & 0.635 & 0.393 & 0.227 & 0.222 & 0.180 & 0.238 & 0.168 & 0.217 & 0.046 \\
\hline$\Sigma \mathrm{A}$ & .00 & 00 & 0 & 6.00 & .00 & 6.00 & 6.00 & 6.00 & 6.00 & 6.00 & 6.00 & 6.00 & 6.00 & 6.00 & 6.00 \\
\hline $\mathrm{Cu}$ & 965 & 4304 & 079 & 154 & 3906 & 4.028 & 1113 & 4236 & 4149 & 3817 & 4.323 & 4.432 & 4.362 & 4.392 & 4.115 \\
\hline $\mathrm{Zn}$ & 132 & 1.057 & 802 & 855 & 223 & 063 & 288 & 1.091 & 0.876 & 1.133 & 0.895 & 1.112 & 0.895 & 1.211 & 1.034 \\
\hline $\mathrm{Fe}$ & 0.787 & 0.930 & 1.122 & 1.079 & 0.659 & 0.919 & 0.675 & 0.914 & 1.099 & 0.777 & 0.951 & 0.806 & 0.979 & 0.707 & 0.879 \\
\hline $\mathrm{Pb}$ & 010 & 0.005 & 0 & 0.000 & 0.000 & 000 & .00 & 0.000 & 0.000 & 0.000 & .000 & 0.000 & 0.000 & .000 & 0.000 \\
\hline $\mathrm{Hg}$ & 049 & 0.045 & 029 & 037 & 0.058 & 0.037 & 0.044 & 0.032 & 0.029 & 0.035 & .019 & 0.027 & 0.017 & 0.024 & 0.008 \\
\hline$\Sigma \mathrm{B}+\mathrm{C}$ & 5.943 & 6.341 & 6.032 & 6.125 & 5.846 & 6.047 & 6.12 & 6.273 & 6.153 & 5.762 & 6.188 & 6.377 & 6.253 & 6.334 & 6.036 \\
\hline As & 119 & 0.569 & 0.946 & 0.759 & 0.251 & 1.302 & 0.275 & 1.357 & 0.299 & 0.220 & 1.171 & 0.652 & 1.083 & 0.417 & 0.702 \\
\hline $\mathrm{Sb}$ & 872 & 3.414 & 031 & 3.224 & 3.739 & 2.689 & 3.706 & 2.627 & 3.680 & 3.768 & 2.829 & 3.348 & 2.896 & 3.567 & 3.283 \\
\hline $\mathrm{Bi}$ & 0.009 & 0.017 & 0.023 & 0.016 & 0.010 & 0.009 & 0.018 & 0.016 & 0 & 0.013 & 0.000 & 0.000 & 0.020 & 0.017 & 0.015 \\
\hline$\Sigma \mathrm{D}$ & 00 & 4.00 & 1.00 & 1.00 & 1.00 & 4.00 & 4.00 & 4.00 & 1.00 & 4.00 & 4.00 & 4.00 & 4.00 & 4.00 & 4.00 \\
\hline $\mathrm{Se}$ & 000 & 0.000 & 0.000 & 013 & 0.000 & 0.035 & 0.000 & 0.012 & 0.000 & 0.000 & 0.000 & 0.000 & 0.000 & 0.000 & 0.010 \\
\hline$S$ & 2.863 & 13.093 & 13.064 & 13.010 & 12.270 & 12.999 & 12.915 & 13.099 & 13.012 & 12.427 & 12.757 & 13.060 & 12.966 & 13.042 & 12.847 \\
\hline$\Sigma Y+Z$ & 12.863 & .093 & 13.064 & 13.023 & 12. & 13.034 & 12.915 & 13.111 & 13.012 & 12.427 & 12.757 & 3.06 & 12.966 & 13.042 & 12.857 \\
\hline $\begin{array}{l}\mathrm{Sb} / \\
(\mathrm{Sb}+\mathrm{As})\end{array}$ & 0.97 & 0.86 & 0.76 & 0.81 & 0.94 & 0.67 & 0.93 & 0.66 & 0.92 & 0.94 & 0.71 & 0.84 & 0.73 & 0.90 & 0.82 \\
\hline
\end{tabular}

b.d.l. - below detection limit.

$\mathrm{A}=\mathrm{Cu}^{+}, \mathrm{Ag}^{+} ; \mathrm{B}+\mathrm{C}=\mathrm{Cu}^{+}, \mathrm{Zn}^{2+}, \mathrm{Fe}^{2+}, \mathrm{Pb}^{2+}, \mathrm{Hg}^{2+} ; \mathrm{D}=\mathrm{As}^{3+}, \mathrm{Sb}^{3+}, \mathrm{Bi}^{3+} ; \mathrm{Y}+\mathrm{Z}=\mathrm{Se}^{2}, \mathrm{~S}^{2-}$. 


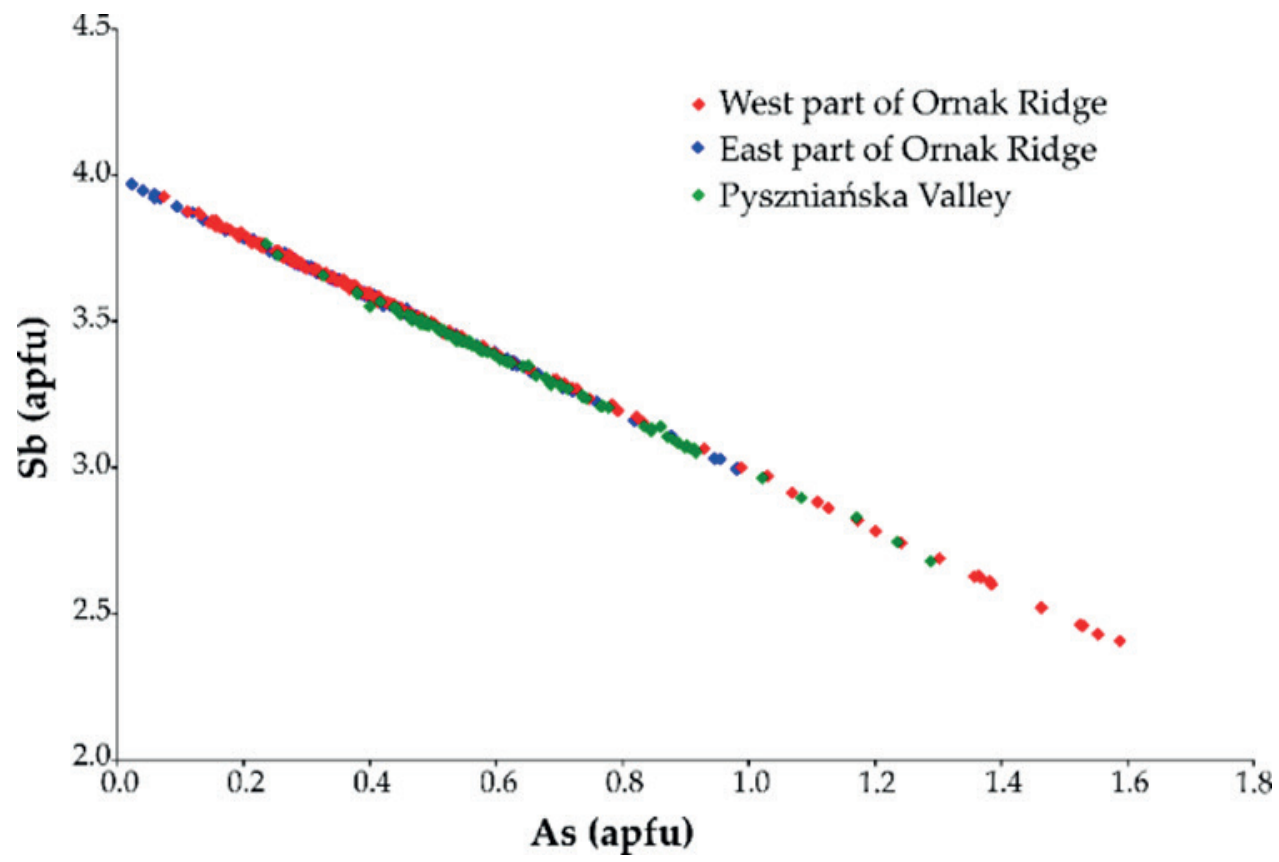

Fig. 8. The Sb-As substitution trend in tetrahedrites from the Polish Tatra Mts.

\section{Table 2}

Representative analyses of chalcopyrite from three areas in the Western Tatra Mts. Sample: ZB7, ZB6 - eastern part of the Ornak Ridge; TZ4, TZ12, HB1, ZP1 - western part of the Ornak Ridge; DP1, DP4, DP15 - Pyszniańska Valley

\begin{tabular}{|c|c|c|c|c|c|c|c|c|c|c|c|c|}
\hline & \multicolumn{4}{|c|}{ Eastern part of the Ornak Ridge } & \multicolumn{4}{|c|}{ Western part of the Ornak Ridge } & \multicolumn{4}{|c|}{ Pyszniańska Valley } \\
\hline & ZB7-2 & ZB7-18 & ZB6-36 & ZB6-68 & TZ4-21 & TZ12-2 & HB1-16 & ZP1-3 & DP10-3 & DP4-2 & DP4-15 & DP15-70 \\
\hline $\mathrm{Zn}$ & 0.00 & 0.00 & 0.00 & 0.00 & 0.00 & 0.00 & 0.00 & 0.00 & 0.00 & 0.05 & 0.00 & 0.07 \\
\hline $\mathrm{Cu}$ & 34.52 & 34.65 & 34.78 & 34.62 & 34.14 & 34.48 & 34.48 & 34.21 & 34.42 & 34.48 & 34.15 & 34.83 \\
\hline $\mathrm{Fe}$ & 29.82 & 30.06 & 30.16 & 30.21 & 29.95 & 30.34 & 30.06 & 30.34 & 30.34 & 30.02 & 30.51 & 30.03 \\
\hline Se & 0.00 & 0.00 & 0.00 & 0.00 & 0.00 & 0.00 & 0.06 & 0.05 & 0.00 & 0.00 & 0.00 & 0.06 \\
\hline$S$ & 34.97 & 35.19 & 35.18 & 34.89 & 34.89 & 34.64 & 35.17 & 34.65 & 35.03 & 34.77 & 34.99 & 34.89 \\
\hline $\mathrm{Ag}$ & 0.00 & 0.00 & 0.00 & 0.00 & 0.00 & 0.11 & 0.09 & 0.40 & 0.00 & 0.00 & 0.00 & 0.00 \\
\hline $\mathrm{Bi}$ & 0.06 & 0.00 & 0.00 & 0.06 & 0.12 & 0.00 & 0.07 & 0.05 & 0.00 & 0.00 & 0.08 & 0.00 \\
\hline $\mathrm{Pb}$ & 0.00 & 0.00 & 0.00 & 0.00 & 0.15 & 0.17 & 0.00 & 0.00 & 0.00 & 0.23 & 0.22 & 0.05 \\
\hline $\mathrm{Hg}$ & 0.00 & 0.00 & 0.00 & 0.00 & 0.00 & 0.00 & 0.00 & 0.00 & 0.00 & 0.00 & 0.00 & 0.06 \\
\hline$\Sigma$ wt. $\%$ & 99.37 & 99.90 & 100.12 & 99.78 & 99.25 & 99.73 & 99.92 & 99.69 & 99.79 & 99.55 & 99.95 & 99.99 \\
\hline \multicolumn{13}{|c|}{ Chemical formula based on $\mathrm{Zn}+\mathrm{Cu}+\mathrm{Fe}+\mathrm{Ag}+\mathrm{Pb}+\mathrm{Hg}=4 \mathrm{apfu}$} \\
\hline $\mathrm{Zn}$ & 0.000 & 0.000 & 0.000 & 0.000 & 0.000 & 0.000 & 0.000 & 0.000 & 0.000 & 0.001 & 0.000 & 0.002 \\
\hline $\mathrm{Cu}$ & 1.008 & 1.006 & 1.007 & 1.003 & 1.000 & 0.998 & 1.003 & 0.992 & 0.999 & 1.003 & 0.990 & 1.008 \\
\hline $\mathrm{Fe}$ & 0.991 & 0.994 & 0.993 & 0.996 & 0.998 & 0.999 & 0.995 & 1.001 & 1.001 & 0.994 & 1.007 & 0.989 \\
\hline $\mathrm{Se}$ & 0.000 & 0.000 & 0.000 & 0.000 & 0.000 & 0.000 & 0.001 & 0.001 & 0.000 & 0.000 & 0.000 & 0.001 \\
\hline$S$ & 2.025 & 2.025 & 2.018 & 2.004 & 2.025 & 1.987 & 2.028 & 1.991 & 2.014 & 2.004 & 2.011 & 2.001 \\
\hline $\mathrm{Ag}$ & 0.000 & 0.000 & 0.000 & 0.000 & 0.000 & 0.002 & 0.001 & 0.007 & 0.000 & 0.000 & 0.000 & 0.000 \\
\hline $\mathrm{Bi}$ & 0.001 & 0.000 & 0.000 & 0.001 & 0.001 & 0.000 & 0.001 & 0.000 & 0.000 & 0.000 & 0.001 & 0.000 \\
\hline $\mathrm{Pb}$ & 0.000 & 0.000 & 0.000 & 0.000 & 0.001 & 0.001 & 0.000 & 0.000 & 0.000 & 0.002 & 0.002 & 0.000 \\
\hline $\mathrm{Hg}$ & 0.000 & 0.000 & 0.000 & 0.000 & 0.000 & 0.000 & 0.000 & 0.000 & 0.000 & 0.000 & 0.000 & 0.001 \\
\hline
\end{tabular}


Table 3

Representative analyses of pyrite from the western part of Tatra Mts. in Poland. Sample: ZB7, ZB9 - eastern part of the Ornak Ridge; HB1 - western part of the Ornak Ridge; DP10, DP15 - Pyszniańska Valley

\begin{tabular}{|l|c|c|c|c|c|c|}
\cline { 2 - 7 } \multicolumn{1}{c|}{} & \multicolumn{2}{c|}{ Eastern part of the Ornak Ridge } & \multicolumn{2}{c|}{ Western part of the Ornak Ridge } & \multicolumn{2}{c|}{ Pyszniańska valley } \\
\cline { 2 - 7 } \multicolumn{1}{c|}{} & ZB7_40 & ZB9_37 & HB1_1 & HB1_3 & DP15_80 & DP10_11 \\
\hline $\mathrm{Cu}$ & 0.00 & 0.39 & 1.35 & 0.53 & 0.09 & 0.22 \\
\hline $\mathrm{Fe}$ & 45.76 & 46.38 & 45.51 & 47.10 & 46.78 & 46.04 \\
\hline $\mathrm{As}$ & 0.45 & 0.00 & 0.00 & 0.14 & 0.00 & 0.00 \\
\hline $\mathrm{Se}$ & 0.00 & 0.05 & 0.00 & 0.00 & 0.00 & 0.00 \\
\hline $\mathrm{S}$ & 52.96 & 53.83 & 52.88 & 53.86 & 53.29 & 53.46 \\
\hline $\mathrm{Sb}$ & 0.00 & 0.15 & 0.51 & 0.18 & 0.00 & 0.00 \\
\hline $\mathrm{Ag}$ & 0.00 & 0.00 & 0.06 & 0.02 & 0.00 & 0.00 \\
\hline $\mathrm{Bi}$ & 0.07 & 0.07 & 0.00 & 0.00 & 0.00 & 0.00 \\
\hline $\mathrm{Swt. \%}$ & 99.25 & 100.86 & 100.31 & 101.83 & 100.16 & 99.72 \\
\hline \multicolumn{7}{|c|}{ Chemical formula based on $\Sigma \mathbf{M e}=\mathbf{2}$ apfu } \\
\hline $\mathrm{Cu}$ & 0.000 & 0.007 & 0.025 & 0.010 & 0.002 & 0.004 \\
\hline $\mathrm{Fe}$ & 0.992 & 0.991 & 0.969 & 0.986 & 0.998 & 0.996 \\
\hline $\mathrm{As}$ & 0.007 & 0.000 & 0.000 & 0.002 & 0.000 & 0.000 \\
\hline $\mathrm{Se}$ & 0.000 & 0.001 & 0.000 & 0.000 & 0.000 & 0.000 \\
\hline $\mathrm{S}$ & 2.000 & 2.003 & 1.961 & 1.964 & 1.981 & 2.014 \\
\hline $\mathrm{Sb}$ & 0.000 & 0.001 & 0.005 & 0.002 & 0.000 & 0.000 \\
\hline $\mathrm{Ag}$ & 0.000 & 0.000 & 0.001 & 0.000 & 0.000 & 0.000 \\
\hline $\mathrm{Bi}$ & 0.000 & 0.000 & 0.000 & 0.000 & 0.000 & 0.000 \\
\hline
\end{tabular}

Table 4

Representative analyses of galena from the eastern part of the Ornak Ridge in the Western Tatra Mts.

\begin{tabular}{|l|c|c|c|}
\cline { 2 - 4 } \multicolumn{1}{c|}{} & ZB4_001 & ZB4_001 & ZB4_002 \\
\hline $\mathrm{Zn}$ & 0.01 & 0.00 & 0.00 \\
\hline $\mathrm{Cu}$ & 0.01 & 0.01 & 0.01 \\
\hline $\mathrm{Fe}$ & 0.02 & 0.03 & 0.02 \\
\hline $\mathrm{Se}$ & 0.02 & 0.00 & 0.06 \\
\hline $\mathrm{S}$ & 13.16 & 13.10 & 13.17 \\
\hline $\mathrm{Cd}$ & 0.34 & 0.06 & 0.13 \\
\hline $\mathrm{Te}$ & 0.01 & 0.00 & 0.03 \\
\hline $\mathrm{Sb}$ & 0.00 & 0.01 & 0.01 \\
\hline $\mathrm{Bi}$ & 0.00 & 0.00 & 0.01 \\
\hline $\mathrm{Pb}$ & 88.31 & 86.35 & 87.75 \\
\hline $\mathrm{Swt. \%}$ & 101.86 & 99.56 & 101.19 \\
\hline & \multicolumn{3}{|c|}{ Chemical formula based on $\Sigma$ Me $=\mathbf{1}$ apfu } \\
\hline $\mathrm{Zn}$ & 0.000 & 0.000 & 0.000 \\
\hline $\mathrm{Cu}$ & 0.000 & 0.000 & 0.000 \\
\hline $\mathrm{Fe}$ & 0.001 & 0.001 & 0.001 \\
\hline $\mathrm{Se}$ & 0.001 & 0.000 & 0.002 \\
\hline $\mathrm{S}$ & 0.955 & 0.978 & 0.966 \\
\hline $\mathrm{Cd}$ & 0.007 & 0.001 & 0.003 \\
\hline $\mathrm{Te}$ & 0.000 & 0.000 & 0.001 \\
\hline $\mathrm{Sb}$ & 0.000 & 0.000 & 0.000 \\
\hline $\mathrm{Bi}$ & 0.000 & 0.000 & 0.000 \\
\hline $\mathrm{Pb}$ & 0.992 & 0.997 & 0.996 \\
\hline
\end{tabular}

LA-ICP-MS analyses were performed for the tetrahedrites and chalcopyrite only (Tab. 5). Besides the major and minor components discussed above, tetrahedrite-(Zn) and tetrahedrite-( $\mathrm{Fe})$ contain $\mathrm{Co}(10-$ 976 ppm, median 95.81 ppm), Hg (7-9600 ppm, median 4100 ppm), Cd (43-735 ppm, median 127 ppm),
In (0.17-14 ppm, median $4.54 \mathrm{ppm}), \mathrm{Mn}$ (2-63 ppm, median $6 \mathrm{ppm})$. Chalcopyrite has much lower trace element contents, e.g. Co (4-148 ppm, median $19 \mathrm{ppm}), \mathrm{Hg}$ (3-2266 ppm, median $13 \mathrm{ppm}), \mathrm{Cd}$ (12-146 ppm, median 15 ppm), In (0.2-18 ppm, median $3 \mathrm{ppm})$ and $\mathrm{Mn}(18-603 \mathrm{ppm}$, median $29 \mathrm{ppm})$. 
Table 5

Trace element contents [ppm] in tetrahedrite and chalcopyrite from the three areas in the Western Tatra Mts. determined by LA-ICP-MS

\begin{tabular}{|c|c|c|c|c|c|c|c|c|c|c|c|c|}
\hline & $\mathrm{Bi}$ & $\mathbf{P b}$ & $\mathrm{Hg}$ & Cd & Co & Mn & $\mathrm{Ge}$ & Ga & Mo & Sn & $\mathrm{Au}$ & In \\
\hline \multicolumn{13}{|c|}{ Eastern part of the Ornak Ridge } \\
\hline \multicolumn{13}{|c|}{ Tetrahedrite series } \\
\hline Median & 1189 & 10.4 & 3243 & 127 & 174 & 3.8 & 2.3 & - & 5.5 & - & 0.26 & 6.8 \\
\hline Mean & 1292 & 18 & 4100 & 228 & 192 & 4.2 & 3.0 & - & 5.5 & - & 0.25 & 6.6 \\
\hline Min & 840 & 2.8 & 1716 & 43.3 & 56.9 & 2.2 & 1.1 & b.d.l. & 1.9 & b.d.l. & 0.09 & 3.6 \\
\hline Max & 2268 & 61.1 & 9358 & 501 & 408 & 6.1 & 6.5 & b.d.l. & 9.1 & b.d.1. & 0.36 & 9.9 \\
\hline \multicolumn{13}{|c|}{ Chalcopyrite } \\
\hline Median & 12.2 & 9.0 & 9.1 & 25.8 & 13.9 & 28.8 & 4.8 & - & 11.4 & - & - & 3.4 \\
\hline Mean & 108 & 146 & 92.2 & 53.2 & 24.9 & 41.4 & 4.8 & - & 26.8 & - & - & 3.9 \\
\hline Min & 2.5 & 1.1 & 3.3 & 12.2 & 4.7 & 18.8 & 4.8 & b.d.l. & 6.0 & b.d.l. & b.d.l. & 1.7 \\
\hline Max & 971 & 1773 & 596 & 122 & 64.9 & 116 & 4.8 & b.d.l. & 93.1 & b.d.l. & b.d.l. & 7.0 \\
\hline \multicolumn{13}{|c|}{ Western part of the Ornak Ridge } \\
\hline \multicolumn{13}{|c|}{ Tetrahedrite series } \\
\hline Median & 811 & 7.3 & 950 & 125 & 24.2 & 6.6 & 3.9 & 3.2 & 25.9 & 1.2 & 0.2 & 4.0 \\
\hline Mean & 864 & 34.5 & 1701 & 199 & 50.4 & 11.6 & 4.7 & 3.2 & 865 & 1.2 & 0.3 & 3.6 \\
\hline Min & 3.2 & 0.6 & 7.3 & 71.4 & 10.0 & 2.9 & 1.5 & 3.2 & 1.5 & 0.9 & 0.1 & 0.2 \\
\hline Max & 2207 & 676 & 6772 & 735 & 976 & 63.0 & 9.9 & 3.2 & 7262 & 1.5 & 1.0 & 13.8 \\
\hline \multicolumn{13}{|c|}{ Chalcopyrite } \\
\hline Median & 12.7 & - & 18.5 & 20.6 & 14.9 & 43.8 & 8.5 & - & 15.3 & - & - & 3.8 \\
\hline Mean & 57.4 & - & 295 & 30.4 & 34.7 & 102 & 8.5 & - & 15.3 & - & - & 6.5 \\
\hline Min & 1.6 & b.d.l. & 4.2 & 14.7 & 3.8 & 24.2 & 8.5 & b.d.l. & 8.5 & b.d.l. & b.d.l. & 0.4 \\
\hline Max & 488 & b.d.l. & 2266 & 80.1 & 148 & 603 & 8.5 & b.d.l. & 22.2 & b.d.l. & b.d.l. & 17.8 \\
\hline \multicolumn{13}{|c|}{ Pyszniańska Valley } \\
\hline \multicolumn{13}{|c|}{ Tetrahedrite series } \\
\hline Median & 2414 & 27.0 & 2056 & 265 & 426 & 6.1 & 3.8 & - & 2.5 & 0.9 & 0.2 & 4.1 \\
\hline Mean & 2349 & 49.0 & 2242 & 221 & 421 & 6.7 & 3.8 & - & 2.5 & 1.1 & 0.2 & 4.5 \\
\hline Min & 1542 & 3.3 & 660 & 92.8 & 290 & 3.1 & 1.9 & b.d.l. & 1.3 & 0.4 & 0.1 & 2.2 \\
\hline $\operatorname{Max}$ & 4040 & 305 & 4780 & 391 & 522 & 13.4 & 5.6 & b.d.l. & 3.6 & 2.1 & 0.7 & 11.6 \\
\hline \multicolumn{13}{|c|}{ Chalcopyrite } \\
\hline Median & 6.8 & - & 56.7 & 110 & 9.4 & 28.6 & 4.0 & - & - & 1.1 & - & 0.5 \\
\hline Mean & 95.4 & - & 298 & 110 & 39.1 & 28.2 & 4.0 & - & - & 1.1 & - & 0.7 \\
\hline Min & 1.4 & b.d.l. & 6.2 & 74.7 & 5.6 & 17.7 & 2.0 & b.d.l. & b.d.l. & 0.8 & b.d.l. & 0.2 \\
\hline Max & 912 & b.d.l. & 1035 & 146 & 130 & 42.3 & 6.0 & b.d.l. & b.d.l. & 1.3 & b.d.l. & 1.7 \\
\hline
\end{tabular}

b.d.l. - below detection limit.

\section{Fluid inclusions and provenance}

Fluid inclusions were studied in quartz from ore veins collected in the Pod Banie Gully and Ornaczański Gully (the eastern part of the Ornak Ridge, samples number: $\mathrm{ZB} 3, \mathrm{CO} 1, \mathrm{CO} 2, \mathrm{O} 20$, O30), Piekło Gully and Baniste (the western part of the Ornak Ridge, sample number: ZP2, ZP3, PI20, TB1, TB2, B20, H20) and in the Pyszniańska Valley (samples number: DP5, DP6, DP9, DP16). In baryte and siderite fluid inclusions were extremely small and therefore were not studied. Objects of the microthermometric studies were as follows: (1) clouds of inclusions situated in zones of the crystal growth (interpreted as primary inclusions), (2) and inclusions along cracks (secondary inclusions). Single isolated inclusions, belonging to the group of the largest inclusions, were also interpreted as primary inclusions. The quartz in the examined samples was filled with a huge amount of small-sized inclusions, usually not exceeding 1-2 $\mu \mathrm{m}$. Larger-sized inclusions $(5-8 \mu \mathrm{m}$ in size) were very rare and only such inclusions were the subject of micro-thermometric studies. One-phase and two-phase inclusions consisted of a gas bubble and liquid were distinguished (Fig. 9A-D).

One-phase inclusions (below $1 \mu \mathrm{m}$ ) were too small to allow for microthermometric measurement, while three-phase inclusions were not observed. Microscopic observations in UV light excluded the presence of hydrocarbons other than methane. The full data set is presented in Tables S1-S3 (attached as supplementary files in online version). In all the measured quartz samples homogenization temperatures $\left(T_{\mathrm{h}}\right)$ were similar. They allowed to distinguish two generations of fluid inclusion taking petrographic criteria into 
account: (1) with the temperature in the range of $120-174^{\circ} \mathrm{C}$ (primary inclusions) and (2) of 97.8 $120^{\circ} \mathrm{C}$ (secondary inclusions). In contrast to homogenization temperatures $\left(T_{\mathrm{h}}\right)$ eutectic temperatures $T_{\mathrm{e}}$ (HydrohaliteIceV $\rightarrow$ IceLV) and final ice melting temperature $T_{\mathrm{m}}$ (Ice) was examined only for large enough inclusions (Fig. 9). This type of inclusions usually appeared in the form of single isolated inclusions (Fig. 9) and have never been found along a healed cracks in the quartz which allowed to interpreted them as primary fluid inclusions. The obtained temperature of final ice melting for primary inclusions in the samples ranges from -14.6 to near $0^{\circ} \mathrm{C}$. The eutectic temperatures $\left(T_{\mathrm{e}}\right)$ measured for primary inclusions in the examined quartz samples from Tatra Mts. is in the range from -20.2 to $-18^{\circ} \mathrm{C}$.

Sulfur $\delta^{34} S$ isotope ratios were measured for tetrahedrites in the quartz veins collected in the
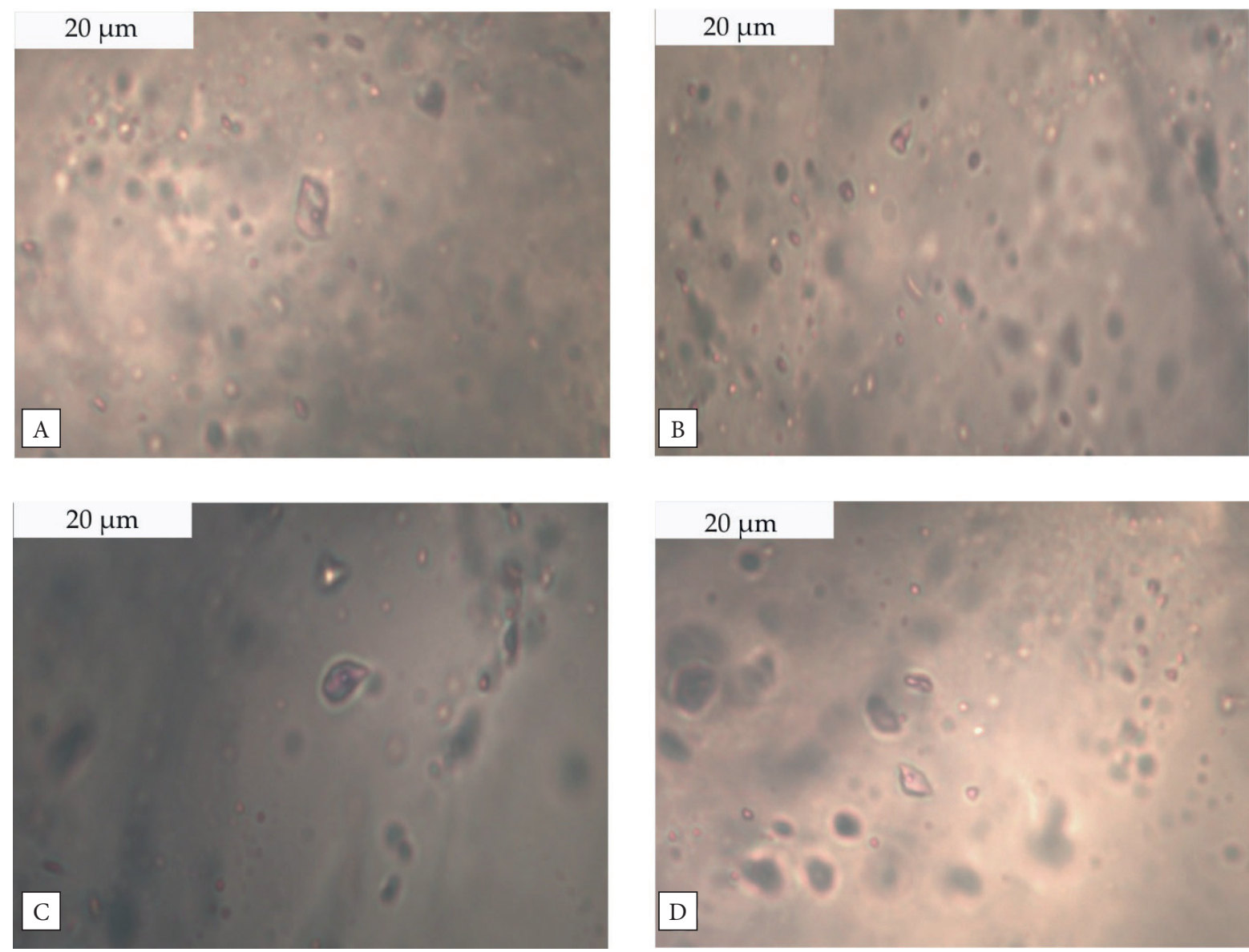

Baniste and Pyszniańska Valley. Measured values $\delta^{34} \mathrm{~S}_{\mathrm{CDT}}$ range from 1.98 to $3.42 \%$. The sulfur isotopic data are presented in Table 6.

\section{Table 6}

Sulphur isotopic data from Western Tatra Mts. Sample: 1 - eastern part of the Ornak Ridge (this study), 2 - the Pysznianska Valley (this study), 3 - Western Tatra Mts. (Gawęda et al. 2007).

\begin{tabular}{|c|c|c|c|}
\hline Location & Mineral & Sample & $\boldsymbol{\delta}^{\mathbf{3 4}} \mathbf{S}_{\mathrm{CDT}}$ \\
\hline 1 & $\mathrm{Ttd}$ & ZPB-4H & 3.33 \\
\hline 1 & $\mathrm{Ttd}$ & ZPB-4H & 3.42 \\
\hline 2 & $\mathrm{Ttd}$ & DP-4H & 1.98 \\
\hline 2 & $\mathrm{Ttd}$ & DP-4H & 2.17 \\
\hline 3 & $\mathrm{Ttd}$ & PB IV & 2.51 \\
\hline 3 & $\mathrm{Ttd}$ & PB-1 & 1.91 \\
\hline 3 & $\mathrm{Ttd}$ & PB-II & 2.90 \\
\hline 3 & $\mathrm{Ttd}$ & PB1 & 2.60 \\
\hline 3 & $\mathrm{Ttd}$ & $\mathrm{AP1}$ & 2.64 \\
\hline 3 & $\mathrm{Ttd}$ & PB V & 2.95 \\
\hline
\end{tabular}

Abbreviation: Ttd - tetrahedrite.
B

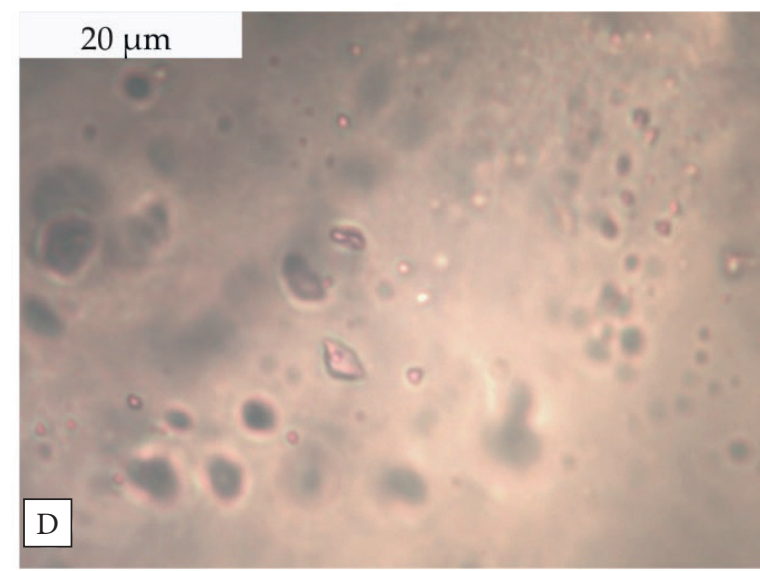

Fig. 9. Fluid inclusions in quartz from the Western Tatra Mts., transmitted light microscopy: A) two-phase inclusions from the Pyszniańska Valley; B), D) a group of inclusions from eastern part of the Ornak Ridge; C) inclusions from the western part of the Ornak Ridge 


\section{DISCUSSION}

\section{Compositional relationships}

The most common primary sulfide minerals in the examined ores are tetrahedrite-(Fe), tetrahedrite-( $\mathrm{Zn})$ and chalcopyrite with minor pyrite and galena contrary to the Slovak part of the Tatra Mts. where chalcopyrite and pyrite were found as the most common ore components and tetrahedrite-group minerals were quite rare (Bakos 2003). The measured Fe and $\mathrm{Zn}$ contents in the studied tetrahedrite-group minerals 1.63$5.05 \mathrm{Fe}$ wt.\% (eastern part of the Ornak Ridge) and 1.83-5.79 $\mathrm{Zn}$ wt.\% (eastern part of the Ornak Ridge) are slightly higher than those noted previously by Gawęda \& Paulo (1998) (3.66 Fe wt.\% and 2.75-4.81 Zn wt.\%, respectively). The presented results are comparable with Wątocki (1951) data in case of $\mathrm{Zn}$ (3.93 Zn wt.\%) and slightly lower in case of Fe amounts (7.54 Fe wt.\%).

A characteristic feature of tetrahedrite-group minerals in the Slovak part of the Tatra Mts. occurrences is prevalence of Fe over $\mathrm{Zn}$ usually in the proportion 1.2-1.8 : 1 (Bakos 2003, Majzlan et al. 2020). Compositional difference between the tetrahedrite-group minerals allowed to distinguish two stages of ore mineralization in the Slovak Tatra Mts. (Majzlan et al. 2020). Tetrahedrite-group minerals with high $\mathrm{Sb} /(\mathrm{Sb}+\mathrm{As})$ ratios and wide $\mathrm{Fe} /(\mathrm{Fe}+\mathrm{Zn})$ range were related to the dolomite/siderite-baryte-tetrahedrite association. The $\mathrm{Sb} /(\mathrm{Sb}+\mathrm{As})$ ratio below 0.8 and the $\mathrm{Fe} /(\mathrm{Fe}+\mathrm{Zn})$ ratio mostly above 0.4 were characteristic for tetrahedrite in the quartz$\mathrm{Cu}$-sulfide association (Bakos 2003, Majzlan et al. 2020). Our results of tetrahedrite-(Fe) and - $(\mathrm{Zn})$ show a high $\mathrm{Sb} /(\mathrm{Sb}+\mathrm{As})$ ratio reaching above 0.8 but lower ratio in the range of $0.6-0.8$ are also observed (Fig. 10). The ratios $\mathrm{Fe} /(\mathrm{Fe}+\mathrm{Zn})$ show a limited range between $0.3-0.6$. This data indicates that the mineralization corresponds the most to dolomite/siderite-baryte-tetrahedrite stage with a narrower range of variation $\mathrm{Fe} /(\mathrm{Fe}+\mathrm{Zn})$.

The obtained average content of $\mathrm{Ag}$ in the studied tetrahedrite-( $\mathrm{Zn})$ and tetrahedrite-( $\mathrm{Fe})$ at around 1.58 wt.\% (eastern part of the Ornak Ridge) is the highest in comparison to those noted in previous studies of the Polish part of the Western Tatra Mts. ores [0.81 wt.\% (Wątocki 1951); 0.63-1.3 wt.\% (Paulo 1979); 0.32-0.47 wt.\% (Gawęda \& Paulo 1998)].
Only in one sample from the western part of the Ornak Ridge was the Ag content higher, reaching 1.9 wt.\% (Paulo 1979). The higher amount of $\mathrm{Ag}$ in the range of 1.5-2 wt.\% was also obtained by Gawęda et al. (2007) in the samples from the Polish part of the Western Tatra Mts. However, it is worth noticing that the maximum Ag content of 4.06 wt.\% recorded in our study was also measured in tetrahedrite from the western part of the Ornak Ridge. For comparison, low Ag amounts of $0.2-0.37 \mathrm{wt} . \%$ were measured in tetrahedrites from the Slovakian part of the Tatra Mts. (Bakos 2003).

In the range of trace elements, the studied tetrahedrites show slight $\mathrm{Bi}$ and $\mathrm{Hg}$ enrichment which however is typical for minerals of this group. The maximum measured Bi content reaches $0.60 \mathrm{wt} . \%$ (Pyszniańska Valley) and Hg 0.96 wt.\% (eastern part of the Ornak Ridge); in case of Bi it is lower than noted in the group of minerals found in the Slovakian part of the Tatra Mts. (0.94-1.99 wt.\%) but comparable for $\mathrm{Hg}$ content (0.01-0.61 wt.\%) (Bakos 2003). Chalcopyrite generally does not contain elevated concentrations of trace elements (Tab. 5). Only 0.20 wt.\% of Bi (Pyszniańska Valley) and no Hg enrichment was documented. The low $\mathrm{Bi}$ and $\mathrm{Hg}$ concentrations in chalcopyrite can be explained by metal partition coefficients that promote the tetrahedrite structure. However, for the same reason it shows higher Mn content (603 ppm in chalcopyrite vs $63 \mathrm{ppm}$ in tetrahedrites from western part of the Ornak Ridge). George et al. (2017) showed that Cd and Co are often present in tetrahedrite-group minerals in concentrations exceeding $1000 \mathrm{ppm}$. In general, the concentration of these metals in tetrahedrites of the Polish part of the Western Tatra Mts. is far below $1000 \mathrm{ppm}$, with the same true for $\mathrm{Ge}, \mathrm{Ga}$, $\mathrm{Mo}$, and Sn which are below $10 \mathrm{ppm}$ or $\mathrm{Au}$ and In below $1 \mathrm{ppm}$. Such a tendency is typical for minerals of the tetrahedrite group crystallized together with chalcopyrite and pyrite which are the primary host for $\mathrm{Sb}, \mathrm{As}, \mathrm{Cu}, \mathrm{Fe}, \mathrm{Zn}$, and $\mathrm{Ag}$ and the secondary host for $\mathrm{Hg}, \mathrm{Cd}$, and Bi (George et al. 2017). Very low In content results from the feature of minerals of that group known as a poor host for Ga, In, and Sn which concentrate rather in co-crystallizing base-metal sulfides (George et al. 2017). 


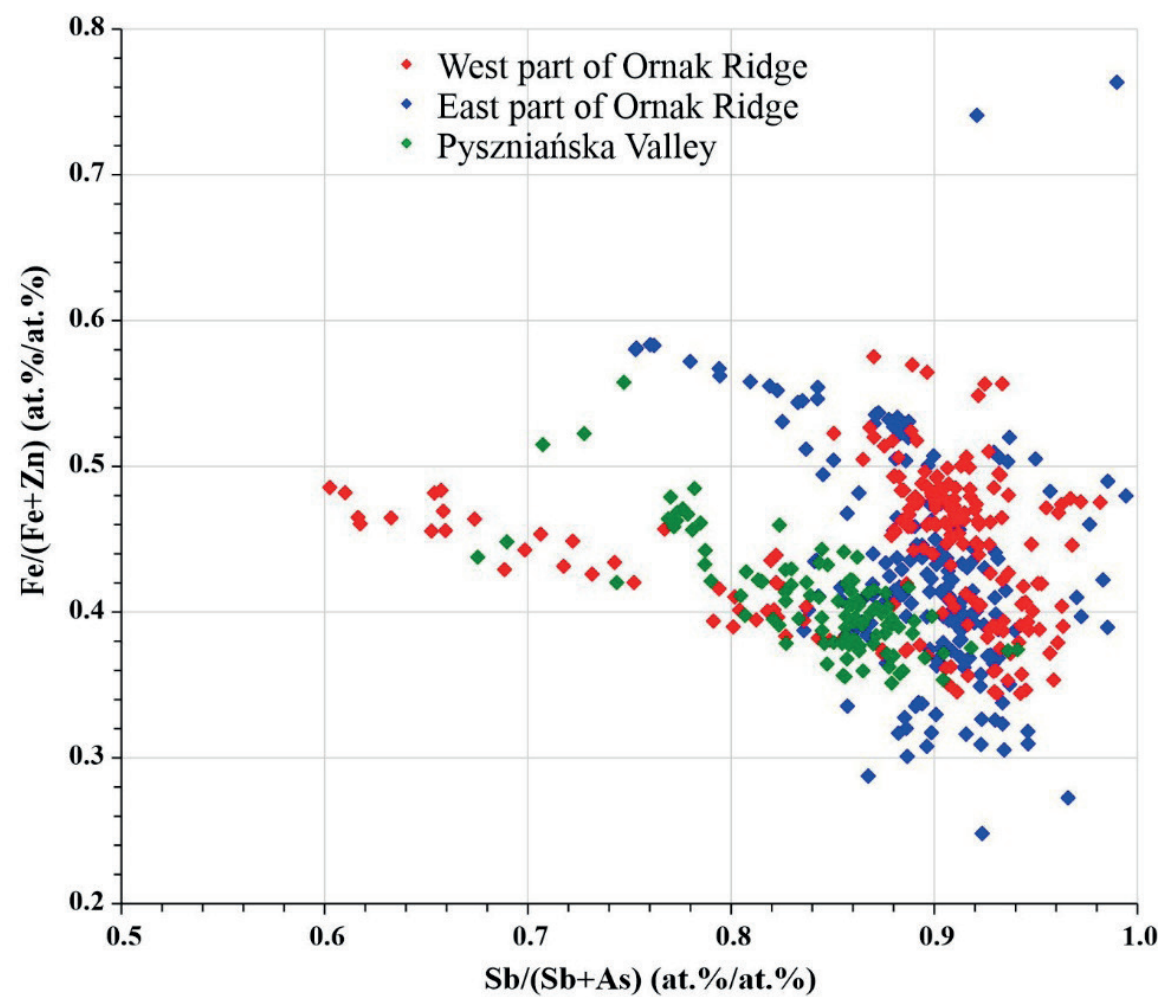

Fig. 10. Correlation between $\mathrm{Fe} /(\mathrm{Fe}+\mathrm{Zn})$ vs. $\mathrm{Sb} /(\mathrm{Sb}+\mathrm{As})$ from three locations in the western part of the Polish Tatra Mts.: west and east part of the Ornak Ridge and Pyszniańska Valley

The amounts of trace elements can provide information about the condition of ore assemblage crystallization. George et al. $(2016,2018)$ indicated that hydrothermal chalcopyrite which crystallized without sphalerite (such is the situation in the Polish part of the Western Tatra Mts. ores) hosts elevated concentrations of $\mathrm{Co}, \mathrm{Zn}, \mathrm{Se}, \mathrm{Ag}$, In, $\mathrm{Sn}$, and Bi. Then, for deposits in which sulfides recrystallized during metamorphism, the amount of $\mathrm{Ga}$ and $\mathrm{Sn}$ is significantly higher in chalcopyrite crystallizing together with sphalerite than in that crystallized alone. Chalcopyrite becomes the preferred host for $\mathrm{Ga}$, Sn, and In during regional metamorphism. In environment with lower temperature and pressure sphalerite is the preferential host for Ga. Indium can also concentrate in chalcopyrite during recrystallization. Tetrahedrite becomes the primary host for $\mathrm{Hg}$ only in the case when concentrations of this element in sphalerite are $\sim 0.001 \mathrm{~mol} \%$ (George et al. 2017). In our research in the Polish part of the Western Tatra Mts., sphalerite was not detected so far and the amount of In in tetrahedrite and chalcopyrite is small, up to $13.8 \mathrm{ppm}$ and $17.8 \mathrm{ppm}$, respectively (western part of the Ornak Ridge). According to George et al. (2016), the presence of In-rich sulfides might suggest their precipitation from high-temperature hydrothermal fluids or recrystallization processes such as metamorphic overprinting. Small amounts of Ga $3.2 \mathrm{ppm}$ in tetrahedrite from the western part of the Ornak Ridge and less than detection limit in chalcopyrite and Sn in the tetrahedrite-group minerals and chalcopyrite (only 2.1 and $1.3 \mathrm{ppm}$ sample from the Pyszniańska Valley, respectively) indicate that the mineralization was formed at low temperature and pressure (George et al. 2016).

Baryte accompanying the Polish part of the Western Tatra Mts. hydrothermal ores (e.g. from the eastern and western part of the Ornak Ridge) revealed wide variation of $\mathrm{Sr}$ contents, reaching maximum $9.4 \mathrm{wt} . \% \mathrm{SrO}$ in sample from eastern part of the Ornak Ridge (M. Sitarz, unpublished data). Wątocki (1951) indicated in the fine-grained baryte up to $6.83 \mathrm{wt} . \%$ of $\mathrm{SrO}$ while in the coarsegrained baryte veins only 1.93 wt.\% SrO. Gawęda 
et al. (2007) reported up to $7.83 \mathrm{wt} . \% \mathrm{SrO}$ in baryte. Increased $\mathrm{SrO}$ can also suggest low-temperature conditions of the baryte crystallization (Zhang et al. 2020).

\section{Fluid inclusions and provenance}

Only fluid inclusions in quartz from hydrothermal ore mineralization crystallized simultaneously with the studied ore assemblage were examined in the Polish and Slovakian parts of the Western Tatra Mts. (Bakos 2003). Fluid inclusions in baryte and siderite were too small for the study. The size of the measurable fluid inclusions in quartz from the both parts was quite similar, $10-15 \mu \mathrm{m}$, mostly $5 \mu \mathrm{m}$. Similarly, primary two-phase inclusions with liquid and vapor were identified in quartz from both parts of the Tatra Mts. Measured homogenization temperature $\left(T_{\mathrm{h}}\right)$ in primary inclusions from quartz from the Slovakian part of the Tatra Mts. ranged from 121 to $201^{\circ} \mathrm{C}$ (Bakos 2003). In the Polish part, these temperatures were slightly lower and of a narrower range $120-174^{\circ} \mathrm{C}$ (supplementary Tabs. S1-S3). The wide range of homogenization temperatures probably reflects the occurrence of two generations of fluid inclusion measured: primary inclusions with $T_{\mathrm{h}}$ in the range of $120-174^{\circ} \mathrm{C}$ and secondary inclusions with $T_{\mathrm{h}}$ in the range of $97-120^{\circ} \mathrm{C}$. Gawęda et al. (2001) presented higher homogenization temperatures for inclusions from dolomites and $\mathrm{Fe}$-dolomites from High Tatra Mts., varying in the range of $190-250^{\circ} \mathrm{C}$, however higher homogenization temperatures may reflect conditions of another mineralization stage not associated with tetrahedrite crystallization. The poor mineral associations of the studied quartz-tetrahedrite veins did not allow for the determination of temperature or pressure with the use of independent mineral geothermobarometers, hence the measured homogenization temperatures in the primary fluid inclusions can be taken as the minimum crystallization temperatures.

The salinity of quartz-tetrahedrite veins in the Slovakian part of the Tatra Mts. range from 14 to 32 wt.\% $\mathrm{NaCl}$ eq. (Bakos 2003). In the Polish part of Tatra Mts., the final ice melting temperatures $T_{\mathrm{m}}$ (Ice), that varying from -14.6 to close to $0^{\circ} \mathrm{C}$ - corresponds to diverse fluids that range from highly mineralized hydrothermal solutions (ca. 18 wt.\% $\mathrm{NaCl}$ eq.) to for almost completely non-mineralized hydrothermal solutions. Lowsalt hydrothermal solutions identified in the study of fluid inclusions may reflect the influence of meteoric waters on the chemistry of hydrothermal solutions. In the Polish part of the Tatra Mts., the eutectic temperature $\left(T_{\mathrm{e}}\right)$ measured indicates the presence of almost pure $\mathrm{NaCl}-\mathrm{H}_{2} \mathrm{O}$ system and probably indicates a small amount of $\mathrm{KCl}$ in the fluids. Higher eutectic temperatures were not measured, which excluded the presence of $\mathrm{CaCl}_{2}$ and $\mathrm{MgCl}_{2}$ salts (Bodnar 2003). In the Slovakian part of the Tatra Mts., the measured eutectic temperatures were higher (Bakos 2003), which indicates the presence of $\mathrm{NaCl}$ and also $\mathrm{NaCl}-\mathrm{Ca}$ $\mathrm{Cl}_{2}$ in the mineralization fluids. The results of the investigation of fluid inclusion in quartz veins with tetrahedrite-chalcopyrite mineralization in the Polish part of the Western Tatra Mts. are similar to the results obtained for post-mylonitic quartz veins from the High Tatra Mts. (Jurewicz \& Kozłowski 2003). In both cases, hydrothermal mineralization probably took place as a result of hydrothermal activity connected with the Variscan granitoid intrusion.

Furthermore, high salinity fluids from which quartz crystallized in the Slovakian part of Tatra Mts. were similar in composition to hydrothermal solutions responsible for quartz-sulfide mineralization in the Spišsko-Gemerské Rudohorie Mts. (Bakos 2003). Fluid inclusion studies from other massifs in the Tatric Superunit gave similar results. In Vyšná Boca (Nízke Tatry Mts.) salinity of fluid inclusions in quartz-chalcopyrite veins fill range $20-24.5$ wt.\%. $\mathrm{NaCl}$ eq. and homogenization temperature varies from 176 to $205^{\circ} \mathrm{C}$. Results from Bacúch (Nízke Tatry Mts.), which indicated salinity in the range of 10-22 wt.\%. $\mathrm{NaCl}$ eq. and $T_{\mathrm{h}}$ of $100-200^{\circ} \mathrm{C}$ are similar for this type of ore mineralization (Bakos 2003). Also, similar are the results from the Mlynná Valley by Majzlan et al. (2001), even though quartz veins with chalcopyrite and tetrahedrite formed are poorly constrained due to the small size of fluid inclusions. The obtained homogenization temperatures evaluated at $157-187^{\circ} \mathrm{C}$ and the salinity at $18-22 \mathrm{wt} . \% \mathrm{NaCl}$ eq. In contrast to the fluid inclusions from the Tatra Mts., where two-phase inclusions were abundant, single phase aqueous fluid inclusions predominate in the Mlynná Valley. 
Generally, studies on fluid inclusions in quartz siderite/dolomite-baryte-tetrahedrite from the Tatric Superunit (Nízke Tatry, Tatry, Malé Karpaty and Strážovské Vrchy) indicate rather low homogenization temperatures $\left(108-157^{\circ} \mathrm{C}\right)$ and salinities mostly between 1 and 14 wt. $\% \mathrm{NaCl}$ eq. (Majzlan 2020). The quartz-Cu-sulfide mineralization that present the second type of mineralization in the Tatric Superunit (Nízke Tatry, Tríbeč, Strážovské Vrchy and Tatra Mts.) have shown homogenization temperature and salinity of 98 $201^{\circ} \mathrm{C}$ and $9-24$ wt. $\% \mathrm{NaCl}$ eq. The fluid composition represents a $\mathrm{NaCl}-\mathrm{KCl}-\mathrm{H}_{2} \mathrm{O}$ system without $\mathrm{CO}_{2}$ (Majzlan 2020). In Pod Babou and Marianka occurrences (Malé Karpaty Mts.) the hydrothermal fluid responsible for the ore mineralization was probably evaporated seawater or a mixture of seawater which mixed with a formation waters from the surrounding rocks (Kubač et al. 2015). The measured low $T_{\mathrm{h}}$ values and low salinity of the fluids representing $\mathrm{NaCl}-\mathrm{H}_{2} \mathrm{O}$ system indicate a crucial influence of meteoritic water (Kubač et al. 2015).

The results presented in this paper mostly indicate the first type of siderite/dolomite-baryte-tetrahedrite ores. It is evidenced by their mineralogy and partly by fluid inclusion data, however, low salinity fluids involved in the origin of examined quartz veins from the Tatras and traces of $\mathrm{KCl}$ in the fluids shows the relationship of the studied mineralization with the second type of mineralization occurring in the Tatric Superunit.

To determine the provenance and evolution of ore-mineralized fluids, $\delta^{34} S$ was measured in tetrahedrite collected in the ore areas from the Polish part of the Western Tatra Mts. The obtained $\delta^{34} \mathrm{~S}_{\mathrm{CDT}}$ values in tetrahedrite from the Baniste Gully and the Pyszniańska Valley, in range of 1.98-3.33\%o (Tab. 6) may suggest the igneous origin of sulfur (Hoefs 2009). Similar studies conducted on tetrahedrite from the Starorobociański and Ornak area (Gawęda et al. 2007) indicated comparable $\delta^{34} \mathrm{~S}$ value of $1.91-2.95 \%$, interpreted by the authors as indicating the same origin. The narrow range of the measured data and heavy isotopic composition suggest rather one source of fluids, however because of the hydrothermal character of the ores the origin of the sulfur might have more than one source. The content of heavier isotopes indicates the lack of biogenic fractionation, in which case we would observe the presence of lighter sulfur (Hoefs 2009, Luptáková et al. 2016).

\section{CONCLUSIONS}

The Tatric Superunit, belonging to the Central Carpathian Mts., hosts many ore deposits in various mountain massifs. This paper is focused on the Polish part of the Tatras, where quartz veins (veinlets) with the siderite/dolomite-baryte-sulfide mineralization with dominant minerals from tetrahedrite group are the most common. This type of ore mineralization is also known from other occurrences in the Slovakian part. Most of tetrahedrite- $(\mathrm{Fe})$ and $-(\mathrm{Zn})$ studied in this work show a high $\mathrm{Sb} /(\mathrm{Sb}+\mathrm{As})$ ratio, above 0.8 .

This study presents new results on the composition and origin of hydrothermal ore mineralization present in the Polish part of the Western Tatra Mts. Ore samples were collected in 7 areas of the Polish Tatra Mts. from all of the recently accessible relics of old ore mining works. The presented work shows the results of mineralogical and geochemical research extended into areas not previously described in the literature. The mineralization is very scarce and its mineralogical diversity and geochemistry are comparable to genetically similar mineralization in the Tatric Superunit.

The main and only recognized primary ore minerals are Ag-bearing tetrahedrite- $(\mathrm{Fe})$ and tetrahedrite-(Zn) with content of $\mathrm{Bi}$ up to $0.3 \mathrm{wt} . \%$ minor chalcopyrite, pyrite and subordinate galena. On the contrary, in the Slovakian part of the Tatra Mts., chalcopyrite predominates in the ores. This may suggest a spatial differentiation in the mineralization style from the south of the Tatra Superunit towards the north. This may be a result of superposition of the carbonate (siderite/dolomite)-baryte-tetrahedrite type ore mineralization with the quartz-Cu-sulfide mineralization type more abundant in the Slovakian part of the Tatra Mts.

The chemical composition of the ore mineralization and the data on fluid inclusions indicate its origin in low-temperature stage in the range of $120-174^{\circ} \mathrm{C}$. The mineralogical and geochemical patterns of the mineralization were formed by partition coefficients of metals transported by the fluids in the form of sulfide and chloride 
complexes among the crystallizing phases, mainly tetrahedrite-group minerals and chalcopyrite. For this reason, tetrahedrite-(Fe) and tetrahedrite-(Zn) are enriched in $\mathrm{Ag}, \mathrm{Zn}, \mathrm{Hg}, \mathrm{As}, \mathrm{Bi}$, Co and $\mathrm{Cd}$ which have a tendency to concentrate in the structure of the group minerals at the absence or limited availability of other base-metal sulfides. The fluid inclusion studies revealed that the fluids featured salinity in the range of $\sim 0-17.92 \mathrm{wt} . \%$ $\mathrm{NaCl}$ eq., which indicates the presence of $\mathrm{NaCl}$ alone or almost alone with small admixture of $\mathrm{KCl}$. The $\delta^{34} \mathrm{~S}$ measurements on selected tetrahedrite grains suggest that igneous fluids might be one of the sources of ores crystallization.

The comparison of the ores mined between the $16^{\text {th }}$ and $18^{\text {th }}$ century in the Polish part of the Western Tatra Mts. with ore mineralization known in other ore occurrences in the Central Carpathians in Slovakia indicates its compatibility with the general model of ore mineralization in the region and its attribution to the siderite/dolomite-barytetetrahedrite mineralization type.

Authors are thankful to the Tatra National Park and Ministry of Environment for enabling field work and samples collection. We thank Agata Duczmal-Czernikiewicz, Štefan Ferenc and the anonymous reviewer for their comments that were very helpful in improving the manuscript. We also acknowledge Adam Pieczka for the comments to this manuscript and Grzegorz Haczewski for English corrections.

This study was supported by the AGH UST grants, 68.68.140.120 and 16.16.140.31.

\section{REFERENCES}

Andráš P., Chovan M., 2005. Gold incorporation into from the Tatric Unit, the Western Carpathians, with respect to their chemical composition. Journal of the Czech Geological Society, 50, 3-4. https://doi.org/10.3190/jcgs.984.

Bakker R.J., 2019. Package fluids. Part 5: The $\mathrm{NaCl}-\mathrm{H}_{2} \mathrm{O}$ system in fluid inclusion research and applications of the software AqSo_NaCl. Chemical Geology, 525, 400-413. https://doi.org/10.1016/j.chemgeo.2019.07.041.

Bakos F., 2003. Hydrotermálne minerálizacje v kryštaliniku Tatier. Univerzita Komenského [Ph.D. thesis].

Bezák V., Biely A., Elecko M., Koneèný V., Mello J., Polák M. \& Potfaj M., 2011. A new synthesis of the geological structure of Slovakia - the general geological map at 1:200 000 scale. Geological Quarterly, 55, 1, 1-8.

Biagioni C., George L. L, Cook N. J., Makovicky E., Moëlo Y., Pasero M., Sejkora J., Stanley C. J., Welch M. D. \& Bosi F.,
2020. The tetrahedrite group: Nomenclature and classification. American Mineralogist, 105, 1, 109-122. https:// doi.org/10.2138/am-2020-7128 109.

Bodnar R.J., 2003. Introduction to aqueous fluid systems. [in:] Samson I., Anderson A. \& Marshall D. (eds.), Fluid Inclusions: Analysis and Interpretation, Mineralogical Association of Canada - Short Course, 32, Mineralogical Association of Canada, Vancouver, 81-99.

Gaweł A., 1966. Itinerarium po śladach robót górniczych w „Srebrnych Górach” w Tatrach Zachodnich. [in:] Maślankiewicz K. (red.), Prace z zakresu historii nauk geologicznych, Prace Muzeum Ziemi, 8, Wydawnictwa Geologiczne, Warszawa, 7-29.

Gawęda A. \& Paulo A., 1998. Mineralizacja pomagmowa stref ścinania w Tatrach Zachodnich. Mineralogical Society of Poland - Special Papers, 11, 84-86.

Gawęda A., Goławska B., Jędrysek M.O., Leichman J., Paulo A. \& Włodyka R., 2001. Carbonate mineralization in the Tatra Mts. Crystalline basement. Mineralogical Society of Poland - Special Papers, 18, 39-42.

Gawęda A., Jędrysek O.M. \& Zieliński G., 2007. Polystage mineralization in tectonic zones in Tatra Mountains, Western Carpathians. [in:] Kozłowski A. \& Wiszniewska J. (eds.), Granitoids in Poland, Archivum Mineralogiae Monograph, 1, Faculty of Geology of the Warsaw University, Warszawa, 341-353.

George L.L., Cook N.J. \& Ciobanu C.L., 2016. Partitioning of trace elements in co-crystallized sphalerite-galenachalcopyrite hydrothermal ores. Ore Geology Reviews, 77, 97-116. https://doi.org/10.1016/j.oregeorev.2016.02.009.

George L.L., Cook N.J. \& Ciobanu C.L., 2017. Minor and Trace Elements in Natural Tetrahedrite-Tennantite: Effects on Element Partitioning among Base Metal Sulphides. Minerals, 7, 17. https://doi.org/10.3390/min7020017.

George L.L., Cook N.J., Crowe B.B. \& Ciobanu C.L., 2018. Trace elements in hydrothermal chalcopyrite. Mineralogical Magazine, 2, 59-88. https://doi.org/10.1180/ minmag.2017.081.021.

Guillong M., Meier D.L., Allan M.M., Heinrich C.A. \& Yardley B.W.D., 2008. Appendix A6: SILLS: A MATLAB-based program for the reduction of laser ablation ICP-MS data of homogeneous materials and inclusions. [in:] Sylvester P. (ed.), Laser Ablation ICP-MS in the Earth Sciences: Current Practices and Outstanding Issues, Mineralogical Association of Canada - Short Course, 40, Mineralogical Association of Canada, Vancouver, 328-333.

Hoefs J., 2009. Stable Isotope Geochemistry. $6^{\text {th }}$ ed. SpringerVerlag Berlin Heidelberg.

Hók J., Pelech O., Teták F., Németh Z. \& Nagy A., 2019. Outline of the geology of Slovakia (W. Carpathians). Mineralia Slovaca, 51, 31-60.

Hurai V., Harčová E., Ozdín D., Prochaska W. \& Wiegerová V., 2002. Origin of siderite veins in the Western Carpathians. I. P-T-X- $\delta 13 \mathrm{C}-\delta 18 \mathrm{O}$ relations in ore-forming brines of the Rudňany deposits. Ore Geology Reviews, 21, 67-101.

Hurai V., Lexa O., Schulmann K., Montigny R., Prochaska W., Frank W., Konecny P., Kral J., Thomas R. \& Chovan M., 2008. Mobilization of ore fluids during Alpine metamorphism: evidence from hydrothermal veins in the Variscan basement of Western Carpathians, Slovakia. Geofluids. https://doi.org/10.1111/j.1468-8123.2008.00216.x. 
Jost H. \& Paulo A., 1985. Złoża dawne, górnictwo i przemysł. Mapa w skali 1:50 000. [in:] Trafas K. (red.), Atlas Tatrzańskiego Parku Narodowego, Tatrzański Park Narodowy, Zakopane; Polskie Towarzystwo Przyjaciół Nauk o Ziemi. Oddział w Krakowie, Kraków, 29.

Jost H., 2004. Dzieje górnictwa i hutnictwa w Tatrach Polskich. Materiały Towarzystwa Muzeum Tatrzańskiego im. dra Tytusa Chałubińskiego w Zakopanem, 12, Muzeum Tatrzańskie, Zakopane.

Jurewicz E. \& Kozłowski A., 2003. Formation conditions of quartz mineralization in the mylonitic zones and on the slickenside fault planes in the High Tatra granitoids. Archiwum Mineralogiczne, 54, 65-76.

Kreutz S., 1918. Sprawozdanie z poszukiwań mineralogiczno-geologicznych w Tatrach zachodnich w r. 1917. [in:] Sprawozdanie Komisji Fizjograficznej obejmujace pogląd na czynności dokonane w ciagu roku 1917 oraz Materjały do fizjografji kraju, 52, Akademja Umiejętności, Kraków, 141-146.

Kubač A., Chovan M., Ozdín D. \& Pukančík L., 2015. Hydrothermal $\mathrm{Pb}-\mathrm{Zn}$ base-metal mineralization at the Marianka locality, the Malé Karpaty Mts. (Slovak republic). Bulletin mineralogicko-petrologického odděleni Národního muzea $v$ Praze, 22, 1, 56-67.

KutaśP., 2005. Górnictwo kruszcowew Tatrach Polskich doIrozbioru Rzeczypospolitej. Wydawnictwo Promo, Kraków.

Liberak A.M., 1927. Górnictwo i hutnictwo w Tatrach polskich. Wierchy, 5, 13-30.

Luptáková J., Milovská S., Jeleň S., Mikuš T., Milovský R. \& Biroň A., 2016. Primary ore Cu mineralization at the Lubietová-Podlipa locality (Slovakia). Acta Geologica Slovaca, 8, 2, 175-194.

Majzlan J., Hurai V. \& Chovan M., 2001. Fluid inclusion study on hydrothermal $\mathrm{As}-\mathrm{Au}-\mathrm{Sb}-\mathrm{Cu}-\mathrm{Pb}-\mathrm{Zn}$ veins in the Mlynná Dolina Valley (Western Carpathians, Slovakia). Gelogica Carpathica, 52, 5, 277-286.

Majzlan J., Berkh K., Koděra P., Števko M., Bakos F. \& Milovský R., 2016. A mineralogical, fluid inclusion, and isotopic study of selected epithermal Ag-Au occurrences in the Banská Štiavnica-Hodruša-Hámre ore district, Western Carpathians. Acta Geologica Slovaca, 8, 2, 133-147.

Majzlan J., Chovan M., Hurai V. \& Luptáková J., 2020. Hydrothermal mineralisation of the Tatric Superunit (Western Carpathians, Slovakia): I. A review of mineralogical, thermometry and isotope data. Geologica Carpathica, 71, 2, 85-112. https://doi.org/10.31577/GeolCarp.71.2.1.

MakovickyE., Chovan M. \& Bakos F., 2007. The stibian mustard gold from the Kriván Au deposit, Tatry Mts., Slovak Republic. Neues Jahrbuch für Mineralogie, Abhandlungen, 184, 2, 207-215. https://doi.org/10.1127/0077-7757/2007/0096.

Mikuš T., Chovan M., 2003. Hydrothermal Sb-Au mineralization in the St Strážovské Vrchy Mountains (Malá Magura, Western Carpathians). Geologica Carpathica, 54, $4,207-216$.
Paulo A., 1970. Mineralizacja barytowo-kwarcowo-siarczkowa w Tatrach w świetle nowych danych. [in:] Pelc A. (red.), Geneza, występowanie i poszukiwanie barytu, Prace Instytutu Geologicznego, 59, Wydawnictwa Geologiczne, Warszawa, 255-266.

Paulo A., 1979. Tatrzańskie złoża kopalin. Przegląd Geologiczny, 27, 7, 396-399.

Pawlica W., 1916. O złożach mineralnych granitu tatrzańskiego. [in:] Sprawozdanie Komisyi Fizyograficznej obejmujace pogląd na czynności dokonane w ciagu lat 1914 i 1915 oraz Materyaly do fizyografii kraju, 50, Akademia Umiejętności Kraków, 155-170.

Piotrowska K. (kier.), 2016. Szczegółowa Mapa Geologiczna Tatr w skali 1: 10000 (SMGT). Państwowy Instytut Geologiczny - Państwowy Instytut Badawczy, Warszawa.

Plašienka D., Grecula P., Putiš M., Kováč, M. \& Hovorka D., 1997. Evolution and structure of the Western Carpathians: an overview. [in:] Grecula P., Hovorka D. \& Putiš M. (eds.), Geological Evolution of the Western Carpathians, Mineralia Slovaca - Monograph, Mineralia Slovaca Corporation-Geocomplex, Bratislava, 1-24.

Radvanec M., Grecula P. \& Žák K., 2004. Siderite mineralization of the Gemericum superunit (Western Carpathians, Slovakia): review and a revised model. Ore Geology Reviews, 24, 267-298. https://doi.org/10.1016/j.oregeorev.2003.07.004.

Števko M., Pršekk J., Smirnov A., Ozdín D., 2009. Chemické zloženie sulfidov a sulfosolí z ložiska Mária-Margita pri Ochtinej. Mineralia Slovaca, 41, 151-158.

Wątocki W., 1951. Żyły mineralne na Ornaku w Tatrach Zachodnich. Rocznik Polskiego Towarzystwa Geologicznego, 20, 11-60.

Zhang X., Zhai S., Yu Z., 2020. Strontium Isotope Compositions of Hydrothermal Barite from the Yonaguni IV: Insight into Fluid/Sediment Interaction and Barite Crystallization Condition. Journal of Ocean University of China volume (Oceanic and Coastal Sea Research), 19, 2, 377-385. https://doi.org/10.1007/s11802-020-4021-4.

Zwoliński S., 1961. Urządzenia kopalni Na Kunsztach w Dolinie Kościeliskiej w Tatrach. Kwartalnik Historii Nauki i Techniki, 6, 3, 457-467.

Zwoliński S., 1962. Badania nad historią górnictwa i hutnictwa w Tatrach Polskich. Etnografia Polska, 6, 163-191.

Supplementary data associated with this article (Tabs.S1-S3) can be found in the online version, at:

https://doi.org/10.7494/geol.2021.47.3.143.

Table S1. Microthermometric data from the western part of the Ornak Ridge, western part of the Polish Tatra Mts.

Table S2. Microthermometric data from the eastern part of the Ornak Ridge, western part of the Polish Tatra Mts.

Table S3. Microthermometric data from the Pyszniańska Valley, western part of the Polish Tatra Mts. 